Article

\title{
Literature Survey and Further Studies on the 3-Alkylation of N-Unprotected 3-Monosubstituted Oxindoles. Practical Synthesis of N-Unprotected 3,3-Disubstituted Oxindoles and Subsequent Transformations on the Aromatic Ring
}

\author{
Eszter Kókai 1,2,3, Gyula Simig ${ }^{2}$ and Balázs Volk ${ }^{2, *}$ \\ 1 Department of Organic Chemistry and Technology, Budapest University of Technology and Economics, \\ P.O.B. 91, 1521 Budapest, Hungary; ekokai@mail.bme.hu \\ 2 Directorate of Drug Substance Development, Egis Pharmaceuticals PLC., P.O.B. 100, 1475 Budapest, \\ Hungary; simig.gyula@egis.hu \\ 3 Department of Materials Technology, GAMF Faculty of Engineering and Computer Science, Pallasz Athéné \\ University, P.O.B. 700, 6001 Kecskemét, Hungary \\ * Correspondence: volk.balazs@egis.hu; Tel.: +36-1-8035874
}

Academic Editor: Roman Dembinski

Received: 5 November 2016; Accepted: 17 December 2016; Published: 26 December 2016

\begin{abstract}
The paper provides a comprehensive review of the base-catalysed C3-alkylation of $\mathrm{N}$-unprotected-3-monosubstituted oxindoles. Based on a few, non-systematic studies described in the literature using butyllithium as the deprotonating agent, an optimized method has now been elaborated, via the corresponding lithium salt, for the selective C3-alkylation of this family of compounds. The optimal excess of butyllithium and alkylating agent, and the role of the halogen atom in the latter (alkyl bromides vs. iodides) were also studied. The alkylation protocol has also been extended to some derivatives substituted at the aromatic ring. Finally, various substituents were introduced into the aromatic ring of the N-unprotected 3,3-dialkyloxindoles obtained by this optimized method.
\end{abstract}

Keywords: oxindole; alkylation; lithiation; regioselectivity; oxidation

\section{Introduction}

The biological activity of 1,3-dihydro- $2 \mathrm{H}$-indol-2-one (oxindole (1), Figure 1 ) derivatives and their structural relationship to indoles render these compounds important targets in medicinal and synthetic organic chemistry. Launched drugs possessing an oxindole skeleton are summarized in Figure 1: the dopamine agonist ropinirole (2) for the treatment of Parkinson's disease and restless legs syndrome; the atypical antipsychotic ziprasidone (3) and two oncology drugs from the tyrosine kinase inhibitor family, sunitinib (4) and the recently launched nintedanib (5). Several other compounds have reached human Phase III [1], Phase II [2] or Phase I [3] clinical trials, and thousands of further oxindole derivatives are or were studied in preclinical testing in various therapeutic fields.

According to the literature, $\mathrm{N}$-unprotected 3-alkyloxindoles 6 can be prepared by condensation of oxindole (1) with ketones or aromatic aldehydes and subsequent reduction of the primarily formed 3-alkylideneoxindoles, 7. However, in the case of aliphatic aldehydes the yields are low because of aldol-type side reactions [4-6]. In order to avoid these difficulties, we disclosed an efficient method for the regioselective synthesis of $\mathrm{N}$-unprotected 3-alkyloxindoles 6, based on the Raney nickel (Ra-Ni) induced 3-alkylation of oxindole (1) with primary and secondary alcohols (Scheme 1) [7-9]. 
<smiles>O=C1Cc2ccccc2N1</smiles>

1<smiles>CCCN(CCC)CCc1cccc2c1CC(=O)N2</smiles>

2<smiles>O=C1Cc2cc(CCN3CCN(c4nsc5ccccc45)CC3)c(Cl)cc2N1</smiles>

3<smiles>CCN(CC)CCNC(=O)c1c(C)[nH]c(/C=C2\C(=O)Nc3ccc(F)cc32)c1C</smiles>

4<smiles>CC(=O)c1ccc2c(c1)NC(=O)/C2=C(/Nc1ccc(N(C)C(=O)CN2CCN(C)CC2)cc1)c1ccccc1</smiles>

Figure 1. Oxindole (1) and marketed drugs with oxindole skeleton (2-5).

This reaction involves a reductive alkylation as the key step: Raney nickel acts as the oxidizing agent in the transformation of the alcohol to the corresponding carbonyl compound, then as the catalyst during the reduction of the in situ-formed 3-alkylideneoxindole.<smiles>O=C1Cc2ccccc2N1</smiles>

1<smiles>[R]C(=O)CC</smiles>

$\mathrm{R}=\mathrm{H}$, alkyl, aryl $\mathrm{R}^{\prime}=$ alkyl, aril

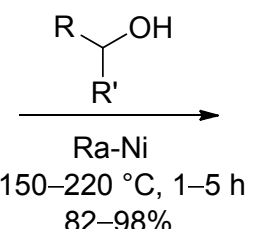
$82-98 \%$<smiles>[R]C([R])=C1C(=O)Nc2ccccc21</smiles>

7

$(E)+(Z)$<smiles>[R]C([R])C1C(=O)Nc2ccccc21</smiles>

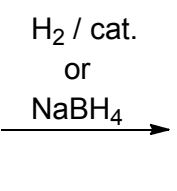

or<smiles>[R]C([R])C1C(=O)Nc2ccccc21</smiles>

6<smiles>O=C1Cc2ccccc2N1</smiles>

Scheme 1. Reductive alkylation reactions of oxindole (1) to give 3-alkyloxindoles 6.

Next we set ourselves the task to develop an efficient method for the 3-alkylation of N-unprotected 3-alkyloxindoles (8, Scheme 2$)$ to give $\mathrm{N}$-unprotected 3,3-dialkyloxindoles 9.<smiles>[R1]C1C(=O)Nc2cc[R1]([H])cc21</smiles>

8<smiles></smiles>

9

Scheme 2. C3-Alkylation of 3-alkyloxindoles 8. 
3-Alkyloxindoles 8 have two regiochemically distinct and easily removable protons (N-H, C3-H), thus rendering possible the formation of $\mathrm{N}$ - and $\mathrm{C} 3$-alkylated products in a deprotonation-alkylation sequence (i.e. alkylation by nucleophilic substitution). In order to find optimal reaction conditions for the regioselective alkylation of 3-alkyloxindoles 8 we first analyzed the results of systematic studies on the alkylation of oxindole (1) described in the literature.

In a systematic study described by Gruda in 1972 [10], alkylation of oxindole (1) with benzyl chloride was carried out in the presence of sodium bases ( $\mathrm{NaOEt}, \mathrm{NaOH})$. Besides the 3,3-dibenzyl derivative (9a) as the main product (20.2\%), 3-benzyl- (8a), 1,3,3-tribenzyl (10a), 1-benzyl- (11) and 1,3-dibenzyloxindole (12) products $(13 \%, 8.1 \%, 6.5 \%$ and 3.6\%, respectively) were isolated by chromatographic separation (Scheme 3). It was demonstrated that, in addition to C-alkylation, $\mathrm{N}$-alkylation also occurred under these conditions.

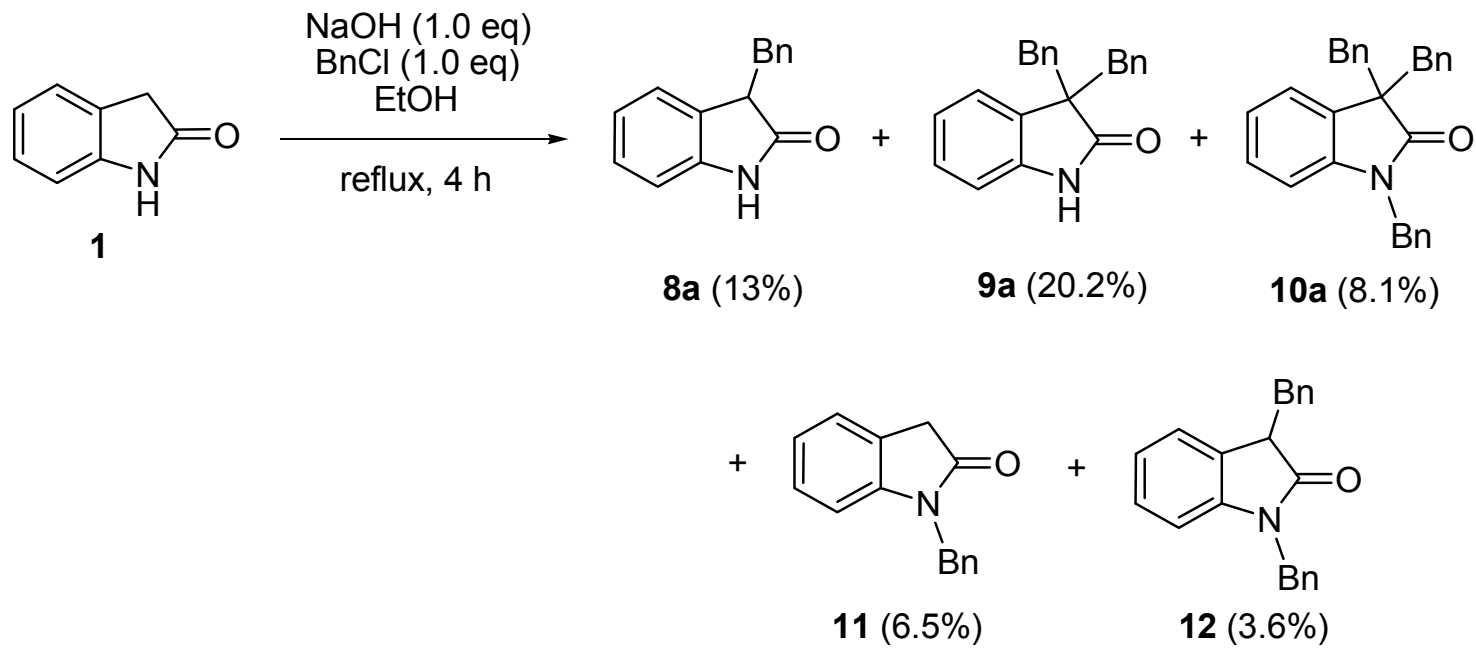

Scheme 3. Direct benzylation of oxindole (1) in the presence of sodium hydroxide.

A protection-deprotection approach was described by Reisch et al. for the synthesis of 3-monosubstituted oxindoles [11]. 3-Acetyloxindole (13), easily available from oxindole (1) [12,13], was alkylated in position 3 in low to moderate yield with various alkyl, alkenyl and alkynyl halides(1.0 eq) in the presence of $\mathrm{NaH}(1.0 \mathrm{eq})$ (Scheme 4).

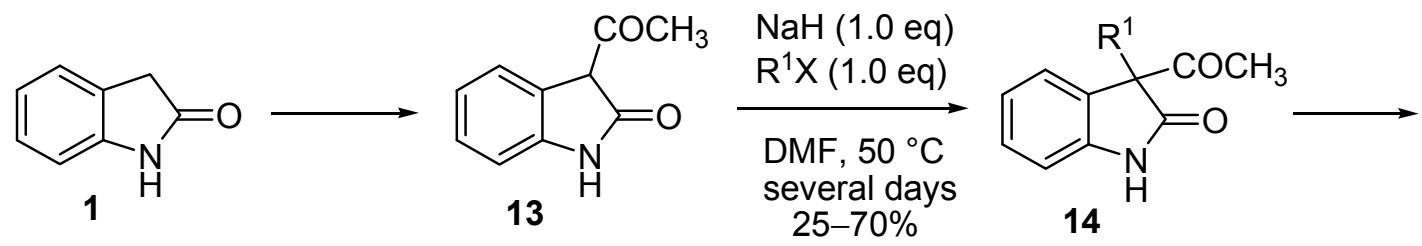

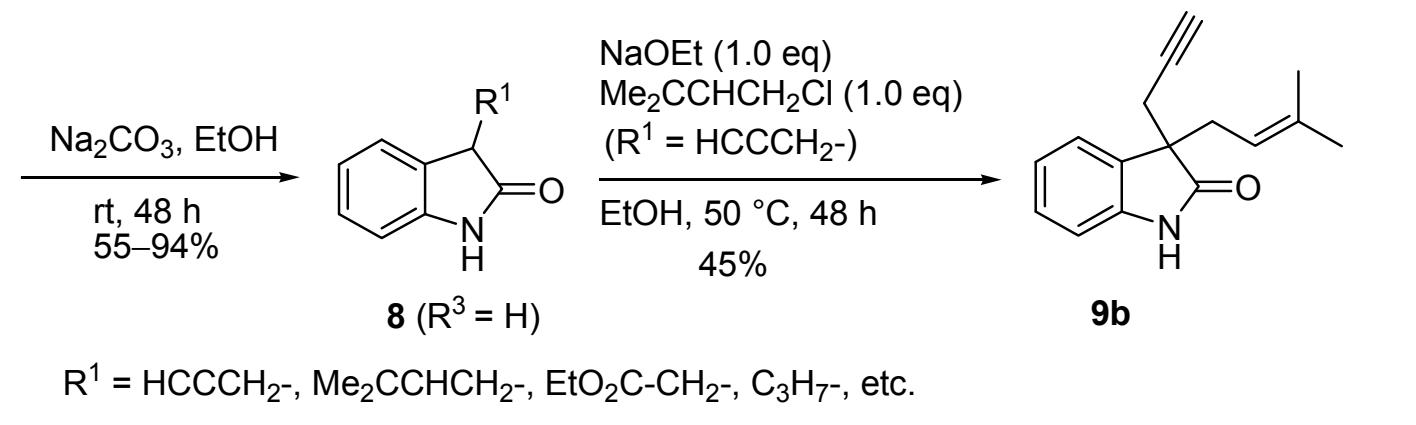

Scheme 4. Alkylation of oxindole (1) via its sodium salt using a protection-deprotection approach. 
The 3-acetyl protecting group increases the acidity of the $\mathrm{C} 3$ position, thereby improving selectivity vs. the N1 atom. 3-Alkyl(alkenyl/ alkynyl)-3-acetyloxindoles $\mathbf{1 4}$ thus obtained were then hydrolysed with $\mathrm{Na}_{2} \mathrm{CO}_{3}$ in EtOH to give 3-monosubstituted derivatives 8, thus rendering the introduction of a second alkyl group into position 3 possible. However, only one representative of this family was described: 3-propargyloxindole was reacted with 3,3-dimethylallylchloride in the presence of NaOEt to give the disubstituted congener $9 \mathbf{b}$ in $45 \%$ yield. The low yield of $9 \mathbf{b}$ may be due to an incomplete selectivity in this step. Nevertheless, this method has several drawbacks: numerous reaction steps, very long reaction times, chromatographic purifications and low overall yield.

In later studies on the 3-alkylation of 3-monosubstituted oxindoles, sodium hydride (1.0-1.1 eq) was used again as the base in the alkylation reaction of 5-fluoro-3-methyloxindole with 2-bromoethyl methyl ether (1.0 eq, 19\% yield after purification by high performance liquid chromatography (HPLC) [14], in the 3-methylation (with 2.9 eq MeI) of 3-arylated 7-fluorooxindole (64\% yield, $93 \%$ purity) [15], and in the reaction of 3-cyclopropyl- or 3-cyclobutyloxindole with MeI (1.0 eq, chromatographic purification, undisclosed yield) [16]. Thus, sodium bases seem to be unsuitable for the high-yielding selective introduction of a second substituent in position C3.

Potassium bases and cesium carbonate also proved to be disadvantageous in several attempted variants: $t$-BuOK in DMF [17], $t$-BuOK in tetrahydrofuran (THF) [18], potassium bis(trimethylsilyl)amide in THF [19], $\mathrm{KI}-\mathrm{K}_{2} \mathrm{CO}_{3}$ in acetone [20,21], $\mathrm{KI}-\mathrm{K}_{2} \mathrm{CO}_{3}$ in THF [21], $\mathrm{K}_{2} \mathrm{CO}_{3}$ in dimethyl acetamide [22,23], and $\mathrm{Cs}_{2} \mathrm{CO}_{3}$ in DMF [24].

Use of a lithium base, first described by Kende et al., proved to be a better approach towards selective C3-alkylation [25], Treatment of oxindole (1) with butyllithium (BuLi, 2.0 eq) in the presence of $N, N, N^{\prime}, N^{\prime}$-tetramethylethylenediamine (TMEDA, 2.0 eq) in THF at $-75^{\circ} \mathrm{C}$ followed by reaction with various alkyl halides at a temperature between $-20{ }^{\circ} \mathrm{C}$ and room temperature gave varying yields of the 3-monosubstituted (8, from $<20 \%$ to $72 \%$ yield) and 3,3-disubstituted (9, from $<20 \%$ to $66 \%$ yield) products (Scheme 5), the ratio of which depended also on the excess of alkylating agent and on the reaction conditions. Besides the pleasing lack of N-alkylation, the major drawbacks of this BuLi-TMEDA protocol are the limited mono/di selectivity, the need for chromatographic purification, and the fact that bromides (except for benzyl bromide and ethyl bromoacetate) were unreactive, therefore the corresponding iodides, which are less easily available and more expensive, had to be used. Two examples are given also for the second alkylation in position 3 under the same conditions: 3-butyloxindole was alkylated with iodomethylcyclohexane (74\% yield) and 3-benzyloxindole with benzyl bromide ( $87 \%)$. It is noteworthy that omission of TMEDA gave poor results in all these reactions.

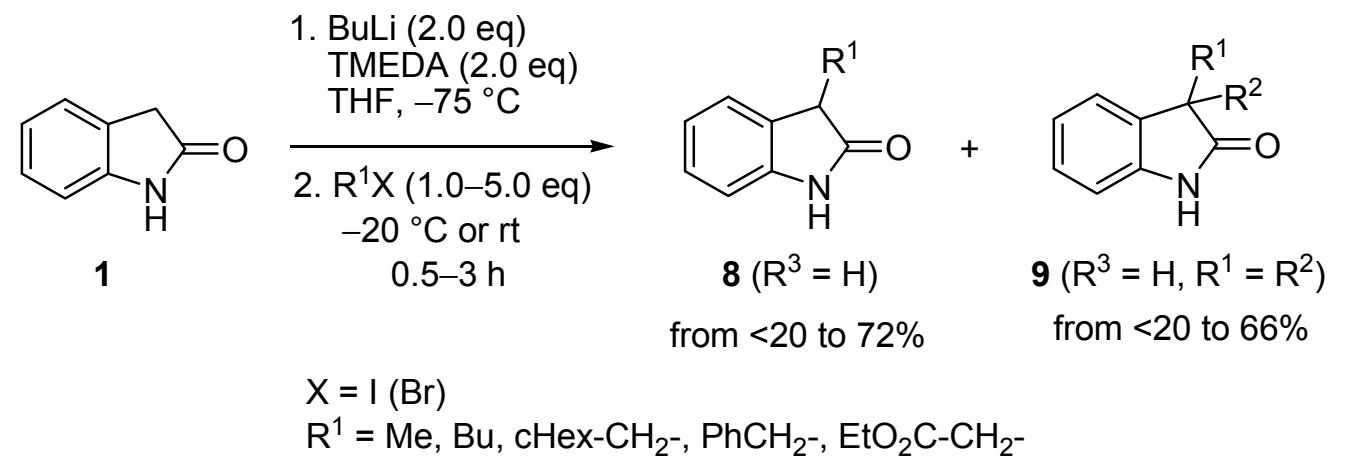

Scheme 5. Direct alkylation of oxindole (1) via its lithium salt.

As demonstrated above, deprotonation with lithium bases offers a more efficient approach towards selective C3-alkylation than alkali metal bases. Since the first step is the formation of a $\mathrm{N}, \mathrm{C}$-dianion, attempts for the selective 3-alkylation of 3-monosubstituted oxindoles $\mathbf{8}$ with less than $2.0 \mathrm{eq} \mathrm{BuLi}$ are always low-yielding. Accordingly, 3-ethylation of 3-methyloxindole (1.0 eq BuLi, 3 eq $\mathrm{LiCl}, 5.0$ eq EtI, THF) [26] or 3-propargylation of 3-ethyloxindole (1.2 eq BuLi, 1.0 eq propargyl 
bromide, THF) [27] gave, after chromatographic purification, 25\% and 55\% yields, respectively. Use of 2.0 eq BuLi led to better results: 3-methyloxindole was 3-methylated (2.0 eq BuLi, 9.4 eq MeI) in 75\% yield after chromatographic purification [28].

The BuLi-TMEDA protocol described by Kende [25] and its slight modifications (2.0-2.5 eq BuLi, 2.0-3.0 eq TMEDA, 1.0-2.2 eq alkyl iodide, THF, $-25{ }^{\circ} \mathrm{C}$ or $-78{ }^{\circ} \mathrm{C} \rightarrow$ r.t.) have been applied by various research groups for the 3-alkylation of 3-monosubstituted oxindoles 8 . Nevertheless, in most cases the yields are not disclosed [16,29,30], or low [31-33]. Only a few successful applications are described. 3-Methyl-6-methoxyoxindole was 3-methylated with methyl iodide (MeI, 82\% yield after flash chromatography) under similar conditions [34]. Instead of alkyl iodides, Jiang et al. used ethyl 2-bromoacetate as the alkylating agent with $60 \%$ yield [35].

Our comprehensive literature search did not reveal further systematic studies (other than those demonstrated in Schemes 3-5) on the synthesis of N-unprotected 3,3-disubstituted oxindoles 9 starting from 3-monosubstituted oxindoles (8). As shown above, due to the biological importance of oxindole derivatives, several research groups applied the above alkylation reactions for the introduction of a second substituent in position 3 of a 3-monosubstituted oxindole 8, albeit, in quite an erratic way.

In the course of our earlier medicinal chemistry studies, selective C3-alkylation of a small number of 3-alkyloxindole derivatives 8 using $\alpha, \omega$-dihaloalkanes ( $2.5 \mathrm{eq})$ was successfully carried out after deprotonation with BuLi (2.5 eq), resulting in 3-alkyl-3-( $\omega$-haloalkyl)oxindole intermediates (15, Scheme 6) [36,37].<smiles>[R][R]1ccc2c(c1)C([R])C(=O)N2</smiles>

$\mathrm{R}^{1}=\mathrm{Et}, i-\mathrm{Bu}$

$\mathrm{R}^{3}=\mathrm{H}, 5-\mathrm{F}, 6-\mathrm{F}$

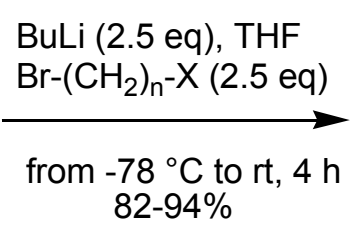

$-94 \%$

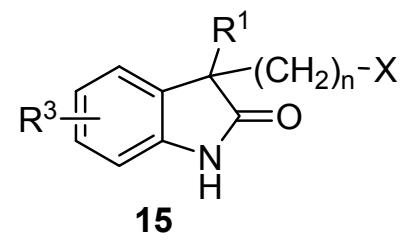

$\mathrm{n}=3,4,5$

$\mathrm{X}=\mathrm{Cl}, \mathrm{Br}$

Scheme 6. Synthesis of 3-alkyl-3-( $\omega$-haloalkyl)oxindoles.

For the sake of completeness it is worth mentioning that, due to the ambident nucleophile character of oxindoles, deprotonation and alkylation can take place not only on C3 or N1, but also on the $\mathrm{O} 2$ atom. To the best of our knowledge, C,O- or C,N-dialkylations are not described. On the other hand, selective O-alkylation can take place under certain conditions, although the occurrence of this reaction in the scientific literature is very rare. It can only be carried out using special alkylating agents, e.g., trialkyloxonium tetrafluoroborates [38-46].

Apart from regioselectivity issues, a further difficulty during the alkylation of oxindole derivarives is caused by the observation that position 3 of 3-monoalkyloxindoles 8 is prone to oxidation under basic conditions. Bai et al. described the synthesis of a wide range of 1-acetyl-3-hydroxy-3-phenacyloxindole derivatives 16 starting from 1-acetyloxindole (17, Scheme 7) and $\alpha$-tosyloxyacetophenone (18, $\mathrm{R}=\mathrm{Ph}$, $\mathrm{X}=\mathrm{OTs}$ ) in an open vial [47]. In a control experiment, the reaction of $\mathbf{1 7}$ and $\alpha$-tosyloxyacetophenone was carried out under nitrogen atmosphere for $8 \mathrm{~h}$, and the 3-monosubstituted oxindole 19 was obtained (yield is not disclosed). Then the reaction was continued $(8 \mathrm{~h})$ by opening the flask, leading to the formation of 3-hydroxy derivative 16, presumably via the corresponding hydroperoxide, the presence of which was proved by electrospray ionization mass spectrometry (ESI-MS). Since the key factor of the suppression of side reactions is the exclusion of atmospheric oxygen, the reductive method elaborated by our research group (Scheme 1) [9] for the synthesis of 3-monoalkyloxindoles 8 is particularly advantageous. 


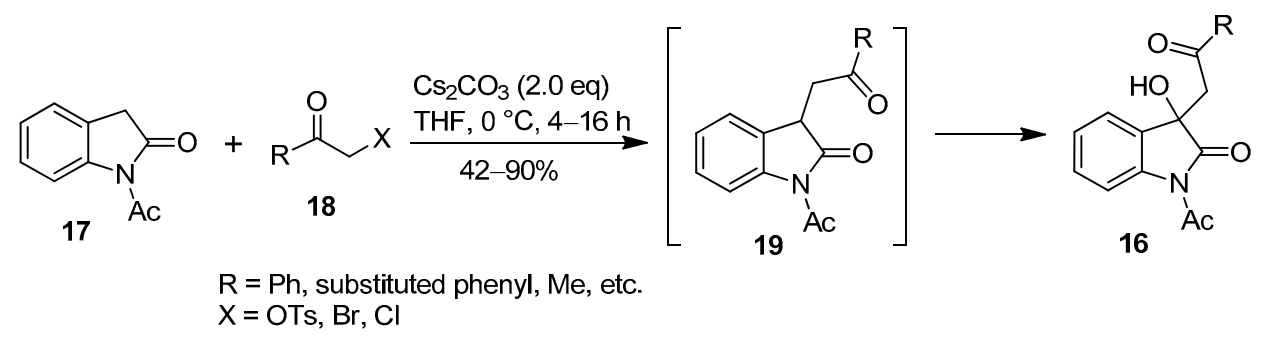

Scheme 7. Synthesis of 1-acetyl-3-hydroxy-3-phenacyloxindole derivatives $\mathbf{1 6 .}$

\section{Results and Discussion}

In the present work we set ourselves the task to carry out a deeper study on the scope and limitations of the deprotonation of 3-monosubstituted oxindoles with BuLi and subsequent alkylation. The advantages of using lithium bases (alkyllithiums, lithium dialkylamides) instead of other alkali metal bases in C-alkylation reactions for deprotonation of $\mathrm{C}-\mathrm{H}$ acids (e.g., ketones, esters, amides) is well documented [48]. Lithium cation, as the smallest alkali metal ion has a stronger tendency to form O-Li and N-Li bonds with increased covalent character [49], thus inhibiting undesirable O- and N-alkylations. 3-Monosubstituted oxindoles 8, optionally substituted on the aromatic ring, as the starting materials of the present study were synthesized from the corresponding isatins [50].

Based on the lithiation-alkylation protocol using BuLi (2.5 eq) and $\alpha, \omega$-dihaloalkanes (2.5 eq) described earlier [36,37], we now aimed at the optimization and application of this method to alkylation with alkyl halides. First, 3-ethyloxindole (8b, Scheme 8$)$ was used as the model compound for the introduction of a second alkyl group. Despite the complete regioselectivity found in our earlier studies with $\alpha, \omega$-dibromoand- $\alpha$-bromo- $\omega$-chloroalkanes [36,37], reaction of $\mathbf{8 b}$ with BuLi (2.5 eq) and MeI (2.5 eq) led to a mixture (Table 1, entry 1) of 3-ethyl-3-methyloxindole (9c, 28\%) and 3-ethyl-1,3-dimethyloxindole (20a, 55\%).<smiles></smiles>

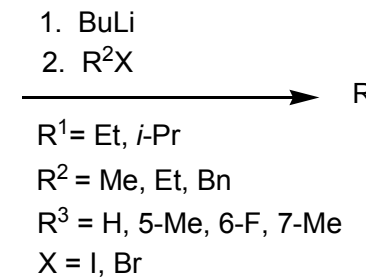<smiles>[R][R]1ccc2c(c1)C([R])([R])C(=O)N2</smiles><smiles>[R]N1C(=O)C([R])([R])c2cc[R1]([NH3+])cc21</smiles>

Scheme 8. Alkylation of 3-ethyloxindoles $\mathbf{8 b - e}$ and 3-isopropyloxindole (8f) with various alkyl halides.

Table 1. Alkylation reactions of 3-ethyloxindoles $\mathbf{8 b}-\mathbf{e}$ and 3-isopropyloxindole (8f) with various alkyl halides.

\begin{tabular}{ccccccccc}
\hline Entry & $\mathbf{8}$ & $\mathbf{R}^{\mathbf{1}}$ & $\mathbf{R}^{\mathbf{3}}$ & $\mathbf{B u L i}(\mathbf{e q})$ & $\mathbf{R}^{\mathbf{2}} \mathbf{X}(\mathbf{e q})$ & $\mathbf{9}$ & 9 Yield (\%) & 20 Yield (\%) \\
\hline 1 & $\mathbf{b}$ & $\mathrm{Et}$ & $\mathrm{H}$ & 2.5 & $\operatorname{MeI}(2.5)$ & $\mathbf{c}$ & $28^{\mathrm{a}}$ & $5^{\mathrm{a}}(\mathbf{2 0 a})$ \\
2 & $\mathbf{b}$ & $\mathrm{Et}$ & $\mathrm{H}$ & 2.2 & $\operatorname{MeI}(1.2)$ & $\mathbf{c}$ & 71 & 0 \\
3 & $\mathbf{b}$ & $\mathrm{Et}$ & $\mathrm{H}$ & 2.5 & $\operatorname{EtI}(2.5)$ & $\mathbf{d}$ & 73 & 0 \\
4 & $\mathbf{b}$ & $\mathrm{Et}$ & $\mathrm{H}$ & 2.2 & $\operatorname{EtBr}(1.2)$ & $\mathbf{d}$ & 90 & 0 \\
5 & $\mathbf{b}$ & $\mathrm{Et}$ & $\mathrm{H}$ & 2.2 & $\operatorname{BnBr}(1.2)$ & $\mathbf{e}$ & 80 & 0 \\
6 & $\mathbf{c}$ & $\mathrm{Et}$ & $5-\mathrm{Me}$ & 2.2 & $\operatorname{EtBr}(1.2)$ & $\mathbf{f}$ & 76 & 0 \\
7 & $\mathbf{d}$ & $\mathrm{Et}$ & $6-\mathrm{F}$ & 2.2 & $\operatorname{EtBr}(1.2)$ & $\mathbf{g}$ & 77 & 0 \\
8 & $\mathbf{e}$ & $\mathrm{Et}$ & $7-\mathrm{Me}$ & 2.2 & $\operatorname{EtBr}(1.2)$ & $\mathbf{h}$ & 66 & 0 \\
9 & $\mathbf{f}$ & $i-\operatorname{Pr}$ & $\mathrm{H}$ & 2.5 & $\operatorname{MeI}(2.5)$ & $\mathbf{i}$ & $40^{\mathrm{a}}$ & $35^{\mathrm{a}}(\mathbf{2 0 b})$ \\
10 & $\mathbf{f}$ & $i-\operatorname{Pr}$ & $\mathrm{H}$ & 2.5 & $\operatorname{MeI}(1.2)$ & $\mathbf{i}$ & 56 & 0 \\
11 & $\mathbf{f}$ & $i-\operatorname{Pr}$ & $\mathrm{H}$ & 2.2 & $\operatorname{EtBr}(1.2)$ & $\mathbf{j}$ & 65 & 0 \\
12 & $\mathbf{f}$ & $i-\operatorname{Pr}$ & $\mathrm{H}$ & 2.2 & $\operatorname{BnBr}(1.2)$ & $\mathbf{k}$ & 63 & 0 \\
\hline
\end{tabular}

${ }^{\mathrm{a}}$ Isolated by flash chromatography. 
This finding is particularly surprising in the light of the paper of Kende et al. that does not describe $\mathrm{N}$-alkylation side-reactions with alkyl iodides [25]. When using decreased excesses of the reagents (2.2 eq BuLi, 1.2 eq MeI), 3,3-dialkyl product $9 \mathrm{c}$ was obtained in $71 \%$ yield, while the formation of 1,3,3-trialkyl derivative 20a could not be detected (entry 2). Unexpectedly, alkylation of $\mathbf{8} \mathbf{b}$ occurred regioselectively even with 2.5 eq of EtI (73\%, entry 3). Change of EtI (2.5 eq) to EtBr (1.2 eq) led to even better results $(90 \%$, entry 4$)$, and the reaction was also performed with $\mathrm{BnBr}(80 \%$, entry 5$)$. Extension of the ethylation (with 1.2 eq EtBr) to derivatives $\mathbf{8 b} \mathbf{b}-\mathbf{e}$ substituted on the aromatic ring was also successful (entries 6-8).

Reactions of 3-isopropyloxindole (8f) gave similar results. Alkylation with 2.5 eq MeI was not regioselective, and led to a mixture of 3-isopropyl-3-methyloxindole (9i, 40\%, Table 1 entry 9) and 3-isopropyl-1,3-dimethyloxindole (20b, 35\%), but use of 1.2 eq MeI afforded uniformly $9 \mathbf{i}$ (entry 10 ). 3-Alkylations could be carried out in a regioselective manner with $1.2 \mathrm{eq} \mathrm{EtBr}$ and $1.2 \mathrm{eq} \mathrm{BnBr}$ to give the corresponding 3-ethyl (9j) and 3-benzyl (9k) derivatives in $65 \%$ and $63 \%$ yields, respectively (entries 11-12).

In order to study the role of TMEDA (applied by Kende et al. during the 3-alkylation reactions of oxindole, 1) [25], a control experiment (analogous to that shown in entry 4 of Table 1) was performed with BuLi/TMEDA (2.2/2.2 eq) using 3-ethyloxindole (8b) as the starting material and ethyl bromide (1.2 eq) as the alkylating agent. The reaction gave practically the same yield ( $88 \%$ vs. $90 \%)$ therefore, considering also that the elimination of TMEDA necessitates extra steps during the work-up of the reaction mixture, it was not applied in our standard alkylation protocol.

The reactions summarized in Table 1 were strictly performed under inert atmosphere. Prior to the reactions, the flask was made inert by using three consecutive vacuum-argon cycles, and an argon atmosphere was maintained until quenching the reaction. However, during the first series of experiments where a less strict pre-inertization was used, significant amounts of the 3-hydroxy side products were isolated. When starting from 3-isopropyloxindole (8f), the alkylation using $2.5 \mathrm{eq} \mathrm{BuLi}$ and 2.5 eq EtBr provided, after work-up a significant amount (23\%) of 3-hydroxy-3-isopropyloxindole (21a, Scheme 9), besides the expected 3-ethyl-3-isopropyloxindole (9i, 36\%).
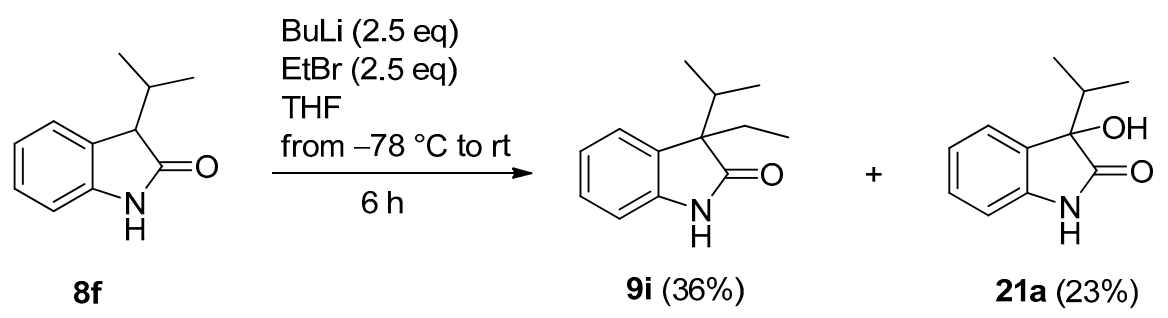

Scheme 9. Ethylation of 3-isopropyloxindole (8f) under insufficiently inert conditions.

The targeted synthesis of the 3-hydroxy derivatives $\mathbf{2 1 a}$, $\mathbf{b}$ was carried out with BuLi (2.5 eq) without alkylating agent and under non-inert conditions with good yields (Scheme 10). The presence of the hydroxy moiety in products $\mathbf{2 1} \mathbf{a}, \mathbf{b}$ renders further functionalizations possible thereby making these compounds valuable synthetic building blocks.<smiles>[R]C1C(=O)Nc2ccccc21</smiles>

8f: $\mathrm{R}^{1}=i-\mathrm{Pr}$ 8b: $R^{1}=E t$
1. BuLi (2.5 eq), $-78^{\circ} \mathrm{C}, 30 \mathrm{~min}$ 2. $\operatorname{air}\left(\mathrm{O}_{2}\right), \mathrm{rt}, 2 \mathrm{~h}$<smiles>[R]C1(O)C(=O)Nc2ccccc21</smiles>

21a: $\mathrm{R}^{1}=i-\operatorname{Pr}(94 \%)$

21b: $\mathbf{R}^{1}=$ Et $(73 \%)$

Scheme 10. 3-Hydroxylation of 3-alkyloxindoles $8 \mathbf{b}, \mathbf{f}$. 
As demonstrated among others by two marketed drugs, ziprasidone (3) and sunitinib (4), and some further drug candidates [51], substitution at position 5 of the aromatic ring is of importance in the oxindole family. A possible approach for the synthesis of 5-substituted 3,3-dialkyloxindoles is 3-alkylation of a 5-subsituted 3-monoalkyloxindole. Nevertheless, several moieties (e.g., $\mathrm{Br}, \mathrm{NO}_{2}$, ortho-directing groups, etc.) can be incompatible with BuLi-mediated 3-alkylation. Therefore, aromatic substitution reactions were carried out, starting from 3,3-diethyloxindole (9d) as the model compound (Scheme 11). Moreover, further modifications of the primarily obtained compounds $\mathbf{9 1 - o}$ have also been envisaged.

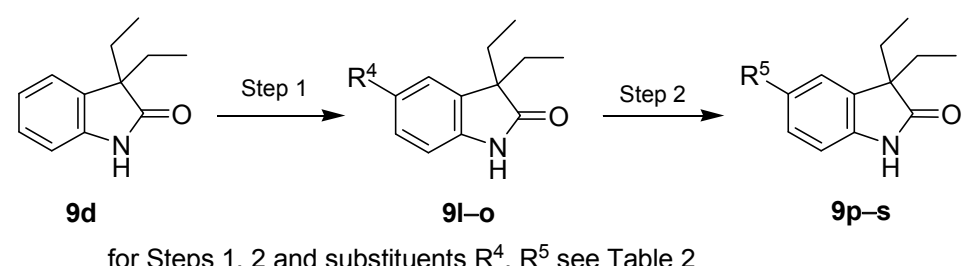

Scheme 11. Various functionalizations of 3,3-diethyloxindole (9d) on the aromatic ring.

First, reaction of $9 \mathbf{d}$ with sulfuryl chloride in glacial acetic acid at $10-15{ }^{\circ} \mathrm{C}$ was carried out to give the 5-chloro congener 91 in $73 \%$ yield (Table 2, entry 1). Bromination of $9 \mathbf{d}$ was performed with bromine and $\mathrm{KBr}$ in aqueous dioxane at $90^{\circ} \mathrm{C}$ to give 5-bromo derivative $9 \mathrm{~m}$ (entry 2 ) in almost quantitative yield. Nitration of $9 \mathrm{~d}$ in a mixture of concentrated sulfuric acid and concentrated nitric acid at $0{ }^{\circ} \mathrm{C}$ (entry 3 ) led to 3,3-diethyl-5-nitrooxindole 9 n, which was reduced by catalytic hydrogenation on palladium on charcoal to 5 -amino derivative $9 \mathrm{p}$. Treatment of starting material $9 \mathrm{~d}$ with sulfurochloridic acid afforded 5-chlorosulfonyl derivative 90 in $98 \%$ yield (entries 4-6). This latter was reacted with ammonia (entry 4), tert-butylamine (entry 5) or morpholine (entry 6) to give the corresponding aromatic sulfonamides $\mathbf{9} \mathbf{q}-\mathbf{s}$.

Table 2. Various functionalizations of 3,3-diethyloxindole (9d) on the aromatic ring.

\begin{tabular}{|c|c|c|c|c|c|c|c|c|}
\hline Entry & $\begin{array}{c}\text { Reagents of } \\
\text { Step } 1^{\text {a }}\end{array}$ & $\begin{array}{l}\text { Product of } \\
\text { Step } 1\end{array}$ & $\mathbf{R}^{4}$ & $\begin{array}{c}\text { Yield of } \\
\text { Step } 1(\%)\end{array}$ & $\begin{array}{l}\text { Reagents of } \\
\text { Step } 2\end{array}$ & $\begin{array}{l}\text { Product of } \\
\text { Step } 2\end{array}$ & $\mathbf{R}^{5}$ & $\begin{array}{c}\text { Yield of } \\
\text { Step } 2(\%)\end{array}$ \\
\hline 1 & $\mathrm{SO}_{2} \mathrm{Cl}_{2}$ & 91 & $\mathrm{Cl}$ & 73 & - & - & - & - \\
\hline 2 & $\mathrm{Br}_{2}, \mathrm{KBr}$ & $9 m$ & $\mathrm{Br}$ & 94 & - & - & - & - \\
\hline 3 & $\begin{array}{l}\mathrm{HNO}_{3} \\
\mathrm{H}_{2} \mathrm{SO}_{4}\end{array}$ & $9 n$ & $\mathrm{NO}_{2}$ & 85 & $\mathrm{H}_{2} / \mathrm{Pd} / \mathrm{C}$ & $9 p$ & $\mathrm{NH}_{2}$ & 87 \\
\hline $\begin{array}{l}4 \\
5 \\
6\end{array}$ & $\mathrm{ClSO}_{3} \mathrm{H}$ & 90 & $\mathrm{SO}_{2} \mathrm{Cl}$ & 98 & $\begin{array}{c}\mathrm{NH}_{3} \\
t \text {-BuNH} \\
\text { morpholine }\end{array}$ & $\begin{array}{l}9 \mathrm{q} \\
9 \mathrm{r} \\
9 \mathrm{~s}\end{array}$ & $\begin{array}{l}\mathrm{NH}_{2} \mathrm{SO}_{2} \\
t \text {-BuNHSO} \\
\text { (morph) } \mathrm{SO}_{2}\end{array}$ & $\begin{array}{l}60 \\
61 \\
76\end{array}$ \\
\hline
\end{tabular}

${ }^{a}$ For Steps 1 and 2, and substituents $\mathrm{R}^{4}, \mathrm{R}^{5}$, see Scheme 11 .

Reaction of 3,3-diethyloxindole (9d) with sulfuryl chloride in glacial acetic acid at $10-15{ }^{\circ} \mathrm{C}$ led to selective 5-chlorination. However, at elevated temperatures $\left(60-80^{\circ} \mathrm{C}\right)$, in accordance with our earlier observations with 3-ethyl-3-( $\omega$-haloalkyl)oxindoles 15 [36,37], the 5,7-dichloro derivative 9t was obtained (Scheme 12). Similar chlorination of 3,3-diethyl-6-fluorooxindole $\mathbf{9 g}$ resulted in 5,7-dichloro-3,3-diethyl-6-fluorooxindole (9u).
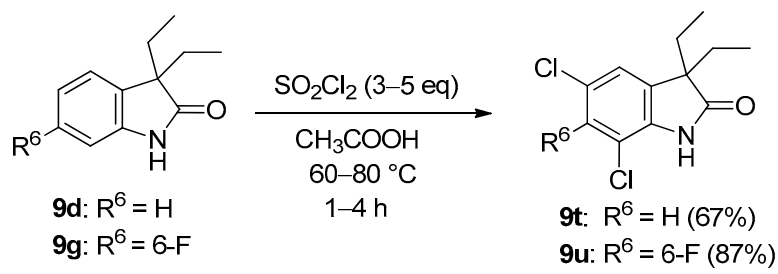

Scheme 12. Synthesis of 5,7-dichloro derivatives $9 \mathbf{t}, \mathbf{u}$. 


\section{Experimental Section}

\subsection{General Information}

All melting points were determined on a Büchi 535 capillary melting point apparatus (Büchi, Flawil, Switzerland) and on an OptiMelt Automated Melting Point System by Stanford Research Systems (Sunnyvale, CA, USA). IR spectra were obtained on a IFS-113v FT spectrometer (Bruker, Billerica, MA, USA). ${ }^{1} \mathrm{H}-\mathrm{NMR}$ and ${ }^{13} \mathrm{C}$-NMR spectra were recorded on a Bruker Avance III (400 and $100 \mathrm{MHz}$ for ${ }^{1} \mathrm{H}$ - and ${ }^{13} \mathrm{C}-\mathrm{NMR}$ spectra, respectively) or a Bruker Avance III HD 600 (600 and $150 \mathrm{MHz}$ for ${ }^{1} \mathrm{H}$ and ${ }^{13} \mathrm{C}$-NMR spectra, respectively) spectrometer (Bruker, Billerica, MA, USA). $\mathrm{CDCl}_{3}, \mathrm{DMSO}-d_{6}$ or $\mathrm{CD}_{3} \mathrm{CN}$ was used as the solvent and tetramethylsilane (TMS) as internal standard. Chemical shifts $(\delta)$ and coupling constants $(J)$ are given in ppm and in $\mathrm{Hz}$, respectively. The electron ionization (EI) mass spectra were recorded on a Clarus 560 D mass spectrometer coupled with a Clarus 500 gas chromatograph (Perkin-Elmer, Waltham, MA, USA). The ESI+ mass spectra (MS) were recorded on a LTQ XL mass spectrometer (Thermo Fisher, Waltham, MA, USA) coupled with an Acquity ${ }^{\mathrm{TM}}$ UPLC (Waters, Milford, MA, USA). Elemental analyses (EA) were performed on a 2400 analyzer (Perkin-Elmer, Waltham, MA, USA) on a VARIO EL III Model CHN elemental analyzer (Elementar, Langenselbold, Germany) or on an Elementar Vario MICRO cube (CHNS) elemental analyzer (Elementar, Langenselbold, Germany). The chloride and bromide contents were determined by titration. The reactions were followed by analytical thin layer chromatography on silica gel $60 \mathrm{~F}_{254}$ (Merck, Darmstadt, Germany). All unspecified reagents were purchased from commercial sources. Compounds $9 \mathbf{a}-\mathbf{b}, \mathbf{9 d}, \mathbf{2 0 a}-\mathbf{b}, \mathbf{2 1 a}$ are known in the literature. Compounds $9 c, 9 m, 9 n, 9 p, 21 b$ are mentioned but poorly characterized in the literature, therefore their full characterization is given below. Compounds $\mathbf{9 e}-\mathbf{1}, \mathbf{9 o}, \mathbf{9 q}-\mathbf{u}$ are new and characterized below.

\subsection{General Procedure I for the Synthesis of Compounds $\mathbf{9 c - h}$ (and By-Product 20a)}

To a mixture of butyllithium in hexane (2.2-2.5 eq, $1.6 \mathrm{M})$ and THF, the solution of the appropriate 3-alkyloxindole $\mathbf{8 b}-\mathbf{e}$ in THF was added dropwise at $-78{ }^{\circ} \mathrm{C}$ under argon atmosphere. Then the appropriate alkyl halide (1.2-2.5 eq) in THF was added dropwise, the acetone-dry ice bath was removed and the reaction mixture was allowed to warm to room temperature. The stirring was continued for further $4 \mathrm{~h}$, the mixture was quenched with ethanol $(\mathrm{EtOH})$ and the solvents were evaporated. The residue crystallized upon treatment with water. It was triturated in water, filtered, washed with water until the $\mathrm{pH}$ was adjusted to 7 , then washed twice with diisopropyl ether (DIPE) and dried. Analytical samples were obtained by recrystallization from the indicated solvents.

3-Ethyl-3-methyl-1,3-dihydro-2H-indol-2-one (9c) [52]. Method A: This compound was prepared according to the general procedure I using BuLi $(4.26 \mathrm{~mL}, 6.82 \mathrm{mmol}, 2.2 \mathrm{eq})$ in THF (3 mL), 8b (500 mg, $3.10 \mathrm{mmol})$ dissolved in THF $(4 \mathrm{~mL})$, and MeI $(232 \mu \mathrm{L}, 528 \mathrm{mg}, 3.72 \mathrm{mmol}, 2.2 \mathrm{eq})$ in THF $(2 \mathrm{~mL})$. The reaction was quenched with EtOH $(1 \mathrm{~mL})$. The product $9 \mathrm{c}$ was obtained as pale yellow crystals (386 mg, 71\%), m.p. $143-144{ }^{\circ} \mathrm{C}$ (hexane-EtOAc), lit. [52] m.p. $143-145{ }^{\circ} \mathrm{C} .{ }^{1} \mathrm{H}-\mathrm{NMR}(600 \mathrm{MHz}$, $\left.\mathrm{CDCl}_{3}\right) \delta 8.32(\mathrm{br} \mathrm{s}, 1 \mathrm{H}), 7.21(\mathrm{dt}, J=7.6,1.1 \mathrm{~Hz}, 1 \mathrm{H}), 7.16(\mathrm{~d}, J=7.3 \mathrm{~Hz}, 1 \mathrm{H}), 7.05(\mathrm{dt}, J=7.5,0.9 \mathrm{~Hz}, 1 \mathrm{H})$, $6.92(\mathrm{dt}, J=7.5,0.9 \mathrm{~Hz}, 1 \mathrm{H}), 1.96-1.93(\mathrm{~m}, 1 \mathrm{H}), 1.81-1.76(\mathrm{~m}, 1 \mathrm{H}), 1.39(\mathrm{~s}, 3 \mathrm{H}), 0.65(\mathrm{t}, J=7.4 \mathrm{~Hz}, 3 \mathrm{H})$. ${ }^{13} \mathrm{C}-\mathrm{NMR}\left(150 \mathrm{MHz}, \mathrm{CDCl}_{3}\right) \delta 183.1,140.5,134.3,127.6,122.9,122.4,109.6,49.4,31.4,23.4,8.9 . \mathrm{IR}(\mathrm{KBr})$ $v 1710,1618 \mathrm{~cm}^{-1}$. MS (ESI): $176.01[\mathrm{M}+\mathrm{H}]^{+}$. EA Calcd. for $\mathrm{C}_{11} \mathrm{H}_{13} \mathrm{NO}$ (175.23): C, 75.40\%; H, 7.48\%; N, 7.99\%. Found: C, 75.69\%; H, 7.36\%; N, 7.96\%. Method B: This compound was prepared according to the general procedure I using BuLi $(4.84 \mathrm{~mL}, 7.75 \mathrm{mmol}, 2.5 \mathrm{eq})$ in THF (4 mL), 8 b (500 mg, $3.10 \mathrm{mmol})$ dissolved in THF $(4 \mathrm{~mL})$, and MeI $(0.48 \mathrm{~mL}, 1.10 \mathrm{~g}, 7.75 \mathrm{mmol}, 2.5 \mathrm{eq})$ in THF $(2 \mathrm{~mL})$. The reaction was quenched with EtOH $(2 \mathrm{~mL})$. The residual oil was purified by gradient elution column chromatography using hexane and ethyl acetate (EtOAc) as the eluents to give $9 \mathrm{c}(150 \mathrm{mg}, 28 \%)$ as colorless crystals.

3-Ethyl-1,3-dimethyl-1,3-dihydro-2H-indol-2-one (20a) [53]. This compound was prepared according to the general procedure I using BuLi $(4.84 \mathrm{~mL}, 7.75 \mathrm{mmol}, 2.5 \mathrm{eq})$ in THF (4 mL), $8 \mathbf{b}(500 \mathrm{mg}, 3.10 \mathrm{mmol})$ 
dissolved in THF $(4 \mathrm{~mL})$, and MeI $(0.48 \mathrm{~mL}, 1.10 \mathrm{~g}$, $7.75 \mathrm{mmol}, 2.5 \mathrm{eq})$ in THF $(2 \mathrm{~mL})$. The reaction was quenched with EtOH $(2 \mathrm{~mL})$. The residual oil was purified by gradient elution column chromatography using hexane and EtOAc as the eluents to give 20 a (320 mg, $1.69 \mathrm{mmol}, 55 \%$ ) as a yellow oil.

3,3-Diethyl-1,3-dihydro-2H-indol-2-one (9d) [54]. Method A: This compound was prepared according to the general procedure I using BuLi $(9.70 \mathrm{~mL}, 15.50 \mathrm{mmol}, 2.5 \mathrm{eq})$ in THF $(10 \mathrm{~mL}), 8 \mathbf{b}(1.00 \mathrm{~g}$, $6.20 \mathrm{mmol})$ dissolved in THF $(8 \mathrm{~mL})$, and ethyl iodide $(1.25 \mathrm{~mL}, 2.71 \mathrm{~g}, 15.50 \mathrm{mmol}, 2.5 \mathrm{eq})$ in THF $(3 \mathrm{~mL})$. The reaction was quenched with $\mathrm{EtOH}(2 \mathrm{~mL})$. The product $9 \mathrm{~d}$ was obtained as colorless crystals $(855 \mathrm{mg}, 73 \%)$, m.p. $158-159{ }^{\circ} \mathrm{C}$ (hexane-EtOAc), lit. [54] m.p. $166-168{ }^{\circ} \mathrm{C}$. Method B: This compound was prepared according to the general procedure I using BuLi ( $344 \mathrm{~mL}, 0.55 \mathrm{~mol}, 2.2 \mathrm{eq}$ ) in THF (100 mL), 8b (40.25 g, $0.25 \mathrm{~mol})$ dissolved in THF ( $300 \mathrm{~mL})$, and ethyl bromide $(22.40 \mathrm{~mL}, 32.69 \mathrm{~g}$, $0.30 \mathrm{~mol}, 1.2 \mathrm{eq})$ in THF $(50 \mathrm{~mL})$. The reaction was quenched with EtOH $(20 \mathrm{~mL})$. The product $9 \mathrm{~d}$ was obtained as colorless crystals $(42.60 \mathrm{~g}, 90 \%)$.

3-Benzyl-3-ethyl-1,3-dihydro-2H-indol-2-one (9e). This compound was prepared according to the general procedure I using BuLi (4.26 mL, $6.82 \mathrm{mmol}, 2.2 \mathrm{eq})$ in THF ( $3 \mathrm{~mL}), 8 \mathbf{b}(500 \mathrm{mg}, 3.10 \mathrm{mmol})$ dissolved in THF ( $4 \mathrm{~mL})$, and benzyl bromide $(442 \mu \mathrm{L}, 636 \mathrm{mg}, 3.72 \mathrm{mmol}, 1.2 \mathrm{eq})$ in THF $(2 \mathrm{~mL})$. The reaction was quenched with $\mathrm{EtOH}(1 \mathrm{~mL})$. The product $9 \mathbf{e}$ was obtained as colorless crystals $(626 \mathrm{mg}, 80 \%)$, m.p. 124-125 ${ }^{\circ} \mathrm{C}$ (hexane-EtOAc). ${ }^{1} \mathrm{H}-\mathrm{NMR}\left(400 \mathrm{MHz}, \mathrm{CDCl}_{3}\right) \delta 7.66$ (br s, $\left.1 \mathrm{H}\right), 7.15-7.11(\mathrm{~m}, 2 \mathrm{H}), 7.05-7.01$ $(\mathrm{m}, 4 \mathrm{H}), 6.90-6.87(\mathrm{~m}, 2 \mathrm{H}), 6.69-6.67(\mathrm{~m}, 1 \mathrm{H}), 3.13(\mathrm{~d}, J=13.04 \mathrm{~Hz}, 1 \mathrm{H}), 3.04(\mathrm{~d}, J=13.05 \mathrm{~Hz}, 1 \mathrm{H})$, 2.12-2.07 (m, 1H), 1.94-1.89 (m, 1H), $0.66(\mathrm{t}, J=7.4 \mathrm{~Hz}, 3 \mathrm{H}) .{ }^{13} \mathrm{C}-\mathrm{NMR}\left(100 \mathrm{MHz}, \mathrm{CDCl}_{3}\right) \delta 181.1,141.0$, 136.0, 131.4, 130.0, 127.7, 127.6, 126.4, 123.9, 122.0, 109.3, 55.7, 43.8, 30.5, 8.7. IR (KBr) v 1717, $1474 \mathrm{~cm}^{-1}$. MS (ESI): $252.14[\mathrm{M}+\mathrm{H}]^{+}$. EA Calcd. for $\mathrm{C}_{17} \mathrm{H}_{17} \mathrm{NO}$ (251.33): C, 81.24\%; $\mathrm{H}, 6.82 \% ; \mathrm{N}, 5.57 \%$. Found: C, $80.88 \% ; \mathrm{H}, 6.78 \%$; N, $5.57 \%$.

3,3-Diethyl-5-methyl-1,3-dihydro-2H-indol-2-one (9f). This compound was prepared according to the general procedure I using BuLi (8.25 mL, $13.20 \mathrm{mmol}, 2.2 \mathrm{eq})$ in THF ( $5 \mathrm{~mL}), 8 \mathrm{c}(1.05 \mathrm{mg}, 6.00 \mathrm{mmol})$ dissolved in THF $(7 \mathrm{~mL})$, and ethyl bromide $(537 \mu \mathrm{L}, 784 \mathrm{mg}, 7.20 \mathrm{mmol}, 1.2 \mathrm{eq})$ in THF $(4 \mathrm{~mL})$. The reaction was quenched with EtOH $(2 \mathrm{~mL})$. The product $9 \mathrm{f}$ was obtained as colorless crystals (930 mg, 76\%), m.p. $155-156{ }^{\circ} \mathrm{C}$ (hexane-EtOAc). ${ }^{1} \mathrm{H}-\mathrm{NMR}\left(400 \mathrm{MHz}, \mathrm{CDCl}_{3}\right) \delta 9.53$ (br s, $\left.1 \mathrm{H}\right), 6.99$ $(\mathrm{dd}, J=7.9,1.0 \mathrm{~Hz}, 1 \mathrm{H}), 6.92(\mathrm{~s}, 1 \mathrm{H}), 6.84(\mathrm{~d}, J=7.8 \mathrm{~Hz}, 1 \mathrm{H}), 2.33(\mathrm{~s}, 3 \mathrm{H}), 1.96-1.82(\mathrm{~m}, 2 \mathrm{H}), 1.81-1.75(\mathrm{~m}$, 2H), $0.64(\mathrm{t}, J=7.4 \mathrm{~Hz}, 6 \mathrm{H}) .{ }^{13} \mathrm{C}-\mathrm{NMR}\left(100 \mathrm{MHz}, \mathrm{CDCl}_{3}\right) \delta 183.3,139.3,132.4,131.5,127.8,123.6,109.3$, 54.9, 30.6, 21.1, 8.6. IR (KBr) v 3170, $1695 \mathrm{~cm}^{-1}$. MS (EI): 203 [M], 175, 174, 156, 146, 130. EA Calcd. for $\mathrm{C}_{13} \mathrm{H}_{17} \mathrm{NO}$ (203.29): C, 76.81\%; H, 8.43\%; N, 6.89\%. Found: C, 76.95\%; H, 8.24\%; N, 7.06\%.

3,3-Diethyl-6-fluoro-1,3-dihydro-2H-indol-2-one $(9 \mathrm{~g})$. This compound was prepared according to the general procedure I using BuLi $(46.06 \mathrm{~mL}, 73.70 \mathrm{mmol}, 2.2 \mathrm{eq})$ in THF $(30 \mathrm{~mL}), 8 \mathrm{~d}(6.00 \mathrm{~g}, 33.50 \mathrm{mmol})$ dissolved in THF ( $45 \mathrm{~mL})$, and ethyl bromide $(3.00 \mathrm{~mL}, 4.38 \mathrm{~g}, 40.20 \mathrm{mmol}, 1.2 \mathrm{eq})$ in THF $(10 \mathrm{~mL})$. The reaction was quenched with $\mathrm{EtOH}(12 \mathrm{~mL})$. The product $9 \mathrm{~g}$ was obtained as colorless crystals (5.31 g, 77\%), m.p. $149-151{ }^{\circ} \mathrm{C}$ (hexane-EtOAc). ${ }^{1} \mathrm{H}-\mathrm{NMR}\left(400 \mathrm{MHz}, \mathrm{CDCl}_{3}\right) \delta 8.84$ (br s, $\left.1 \mathrm{H}\right), 7.04$ (dd, $J=8.2,5.3 \mathrm{~Hz}, 1 \mathrm{H}), 6.74(\mathrm{ddd}, J=9.6,8.2,2.4 \mathrm{~Hz}, 1 \mathrm{H}), 6.69(\mathrm{dd}, J=8.8,2.4 \mathrm{~Hz}, 1 \mathrm{H}), 1.97-1.88(\mathrm{~m}, 2 \mathrm{H})$, $1.83-1.73(\mathrm{~m}, 2 \mathrm{H}), 0.64(\mathrm{t}, J=7.4 \mathrm{~Hz}, 6 \mathrm{H}) .{ }^{13} \mathrm{C}-\mathrm{NMR}\left(100 \mathrm{MHz}, \mathrm{CDCl}_{3}\right) \delta 183.1,162.4(\mathrm{~d}, J=243.8 \mathrm{~Hz})$, $142.6(\mathrm{~d}, J=11.8 \mathrm{~Hz}), 127.7,123.9(\mathrm{~d}, J=9.5 \mathrm{~Hz}), 108.6(\mathrm{~d}, J=22.1 \mathrm{~Hz}), 98.2(\mathrm{~d}, J=27.5 \mathrm{~Hz}), 54.6,30.6,8.6$. IR $(\mathrm{KBr}) \vee 3128,1722,1140 \mathrm{~cm}^{-1}$. MS (EI): 207 [M], 178, 160, 150, 135, 108. EA Calcd. for $\mathrm{C}_{12} \mathrm{H}_{14} \mathrm{FNO}$ (207.25): C, 69.55\%; H, 6.81\%; N, 6.76\%. Found: C, 69.19\%; H, 6.99\%; N, 6.92\%.

3,3-Diethyl-7-methyl-1,3-dihydro-2H-indol-2-one (9h). This compound was prepared according to the general procedure I using BuLi (3.92 mL, $6.28 \mathrm{mmol}, 2.2 \mathrm{eq})$ in THF ( $2 \mathrm{~mL}), 8 \mathrm{e}(500 \mathrm{mg}, 2.85 \mathrm{mmol})$ dissolved in THF $(9 \mathrm{~mL})$, and ethyl bromide $(255 \mu \mathrm{L}, 373 \mathrm{mg}, 3.42 \mathrm{mmol}, 1.2 \mathrm{eq})$ in THF ( $2 \mathrm{~mL})$. The reaction was quenched with $\mathrm{EtOH}(1 \mathrm{~mL})$. The product $9 \mathrm{~h}$ was obtained as colorless crystals (380 mg, 66\%), m.p. $120-121{ }^{\circ} \mathrm{C}$ (hexane). ${ }^{1} \mathrm{H}-\mathrm{NMR}\left(400 \mathrm{MHz}, \mathrm{CDCl}_{3}\right) \delta 8.21$ (br s, $\left.1 \mathrm{H}\right), 7.03-7.01$ $(\mathrm{m}, 1 \mathrm{H}), 6.99-6.94(\mathrm{~m}, 2 \mathrm{H}), 2.28(\mathrm{~s}, 3 \mathrm{H}), 1.97-1.88(\mathrm{~m}, 2 \mathrm{H}), 1.83-1.74(\mathrm{~m}, 2 \mathrm{H}), 0.63(\mathrm{t}, J=7.4 \mathrm{~Hz}, 6 \mathrm{H})$. ${ }^{13} \mathrm{C}-\mathrm{NMR}\left(100 \mathrm{MHz}, \mathrm{CDCl}_{3}\right) \delta 182.4,140.0,132.0,128.9,122.3,120.5,118.4,55.1,30.7,16.5,8.7$. IR $(\mathrm{KBr})$ 
v 2966, $1698 \mathrm{~cm}^{-1}$. MS (EI): 203 [M], 175, 174, 156, 146, 130, 115. EA Calcd. for $\mathrm{C}_{13} \mathrm{H}_{17} \mathrm{NO}$ (203.29): C, $76.81 ; \mathrm{H}, 8.43 ; \mathrm{N}, 6.89 \%$. Found: C, 76.87; H, 8.33; N, 7.07\%.

\subsection{General Procedure II for the Synthesis of Compounds $\mathbf{9 i - \mathbf { k }}$ (and By-Product 20b)}

To a mixture of BuLi in hexane (2.2-2.5 eq, $1.6 \mathrm{M}$ ) and THF, the solution of 3-isopropyloxindole (8f) in THF was added dropwise at $-78{ }^{\circ} \mathrm{C}$, under argon atmosphere. Then the appropriate alkyl halide (1.2-2.5 eq) in THF was added dropwise, the acetone-dry ice bath was removed and the reaction mixture was allowed to warm to room temperature. The stirring was continued for further 4-6 h. The mixture was quenched with $\mathrm{EtOH}(2 \mathrm{~mL})$, saturated ammonium chloride solution $(10 \mathrm{~mL})$ was added, then it was stirred for $30 \mathrm{~min}$. The layers were separated and the aqueous layer was extracted with EtOAc $(3 \times 10 \mathrm{~mL})$. The combined organic layer was washed with brine $(10 \mathrm{~mL})$, dried over anhydrous $\mathrm{MgSO}_{4}$, filtered and the solvent was removed in vacuo at $40{ }^{\circ} \mathrm{C}$. The residue crystallized upon treatment with hexane $(5 \mathrm{~mL})$, then it was filtered. Analytical samples were obtained by recrystallization from the indicated solvents.

3-Isopropyl-3-methyl-1,3-dihydro-2H-indol-2-one (9i). Method A: This compound was prepared according to the general procedure II using BuLi ( $4.46 \mathrm{~mL}, 7.13 \mathrm{mmol}, 2.5 \mathrm{eq})$ in THF $(2 \mathrm{~mL}), 8 \mathrm{f}(500 \mathrm{mg}, 2.85 \mathrm{mmol})$ dissolved in THF ( $6 \mathrm{~mL})$, and MeI $(213 \mu \mathrm{L}, 485 \mathrm{mg}, 3.42 \mathrm{mmol}, 1.2 \mathrm{eq})$ in THF ( $2 \mathrm{~mL})$. The product 9i was obtained as colorless crystals $(300 \mathrm{mg}, 56 \%)$, m.p. $126-127{ }^{\circ} \mathrm{C}$ (hexane-EtOAc). ${ }^{1} \mathrm{H}-\mathrm{NMR}$ $\left(600 \mathrm{MHz}, \mathrm{CDCl}_{3}\right) \delta 8.08$ (br s, 1H), 7.26-7.18 (m, 2H), 7.02 (dt, J = 7.6, 1.0 Hz, 1H), $6.90(\mathrm{~d}, J=7.7 \mathrm{~Hz}$, $1 \mathrm{H}), 2.13(\mathrm{sp}, J=6.7 \mathrm{~Hz}, 1 \mathrm{H}), 1.40(\mathrm{~s}, 3 \mathrm{H}), 1.02(\mathrm{~d}, J=7.0 \mathrm{~Hz}, 3 \mathrm{H}), 0.79(\mathrm{~d}, J=7.7 \mathrm{~Hz}, 3 \mathrm{H}) .{ }^{13} \mathrm{C}-\mathrm{NMR}$ $\left(150 \mathrm{MHz}, \mathrm{CDCl}_{3}\right) \delta 183.0,140.5,133.5,127.5,123.8,122.1,109.4,52.0,35.4,21.5,17.5,17.1 . \mathrm{IR}(\mathrm{KBr}) v$ 3185, 1717, $1670 \mathrm{~cm}^{-1}$. MS (ESI): 190.06 [M + H] $]^{+}$. EA Calcd. for $\mathrm{C}_{12} \mathrm{H}_{15} \mathrm{NO}$ (189.26): C, 76.16; $\mathrm{H}, 7.99$; N, 7.40\%. Found: C, 75.89; H, 7.72; N, 7.61\%. Method B: This compound was prepared according to the general procedure II using BuLi (4.46 mL, $7.13 \mathrm{mmol}, 2.5 \mathrm{eq})$ in THF $(2 \mathrm{~mL}), 8 \mathrm{ff}(500 \mathrm{mg}, 2.85 \mathrm{mmol})$ dissolved in THF (6 mL), and MeI ( $444 \mu \mathrm{L}, 1012 \mathrm{mg}, 7.13 \mathrm{mmol}, 2.5 \mathrm{eq})$ in THF ( $2 \mathrm{~mL})$. The residual oil was purified by gradient elution column chromatography using hexane and EtOAc as the eluents to give $9 \mathbf{i}(216 \mathrm{mg}, 40 \%)$ as colorless crystals.

3-Isopropyl-1,3-dimethyl-1,3-dihydro-2H-indol-2-one (20b) [55]. This compound was prepared according to the general procedure II using BuLi $(4.46 \mathrm{~mL}, 7.13 \mathrm{mmol}, 2.5 \mathrm{eq})$ in THF ( $2 \mathrm{~mL}), 8 \mathrm{f}(500 \mathrm{mg}$, $2.85 \mathrm{mmol})$ dissolved in THF (6 mL), and MeI ( $444 \mu \mathrm{L}, 1012 \mathrm{mg}, 7.13 \mathrm{mmol}, 2.5 \mathrm{eq})$ in THF ( $2 \mathrm{~mL})$. The residual oil was purified by gradient elution column chromatography using hexane and EtOAc as the eluents to give $\mathbf{2 0 b}(200 \mathrm{mg}, 35 \%)$ as yellow oil, lit. [55] m.p. $54{ }^{\circ} \mathrm{C}$. Spectral data are identical with those described in the literature [55].

3-Ethyl-3-isopropyl-1,3-dihydro-2H-indol-2-one (9j). This compound was prepared according to the general procedure II using BuLi ( $7.85 \mathrm{~mL}, 12.55 \mathrm{mmol}, 2.2 \mathrm{eq})$ in THF $(8 \mathrm{~mL}), 8 \mathrm{ff}(1.00 \mathrm{~g}, 5.70 \mathrm{mmol})$ dissolved in THF (12 mL), and ethyl bromide $(0.51 \mathrm{~mL}, 0.75 \mathrm{~g}, 6.84 \mathrm{mmol}, 1.2 \mathrm{eq})$ in THF $(2 \mathrm{~mL})$. The product $9 \mathbf{j}$ was obtained as colorless crystals $(0.76 \mathrm{mg}, 65 \%)$, m.p. $103-104{ }^{\circ} \mathrm{C}$ (hexane). ${ }^{1} \mathrm{H}-\mathrm{NMR}$ $\left(600 \mathrm{MHz}, \mathrm{CDCl}_{3}\right) \delta 8.54(\mathrm{br} \mathrm{s}, 1 \mathrm{H}), 7.20(\mathrm{dt}, J=7.6,1.2 \mathrm{~Hz}, 1 \mathrm{H}), 7.15(\mathrm{~d}, J=7.4 \mathrm{~Hz}, 1 \mathrm{H}), 7.03(\mathrm{dt}$, $J=7.5,1.0 \mathrm{~Hz}, 1 \mathrm{H}), 6.90(\mathrm{~d}, J=7.8 \mathrm{~Hz}, 1 \mathrm{H}), 2.15(\mathrm{sp}, J=6.8 \mathrm{~Hz}, 1 \mathrm{H}), 1.93(\mathrm{q}, J=7.3 \mathrm{~Hz}, 2 \mathrm{H}), 1.01$ $(\mathrm{d}, J=7.0 \mathrm{~Hz}, 3 \mathrm{H}), 0.77(\mathrm{~d}, J=6.8 \mathrm{~Hz}, 3 \mathrm{H}), 0.60(\mathrm{t}, J=7.4 \mathrm{~Hz}, 3 \mathrm{H}) .{ }^{13} \mathrm{C}-\mathrm{NMR}\left(150 \mathrm{MHz}, \mathrm{CDCl}_{3}\right) \delta 182.6$, 141.6, 131.5, 127.5, 123.9, 122.0, 109.3, 57.6, 35.1, 28.2, 17.5, 17.2, 8.8. IR (KBr) v 3164, 1717, $1668 \mathrm{~cm}^{-1}$. MS (ESI): $204.06[\mathrm{M}+\mathrm{H}]^{+}$. EA Calcd. for $\mathrm{C}_{13} \mathrm{H}_{17} \mathrm{NO}$ (203.29): $\mathrm{C}, 76.81 \% ; \mathrm{H}, 8.43 \%$;, $6.89 \%$. Found: C, $76.91 \% ; \mathrm{H}, 8.08 \%$; N, 7.02\%.

3-Benzyl-3-isopropyl-1,3-dihydro-2H-indol-2-one (9k). This compound was prepared according to the general procedure II using BuLi $(7.85 \mathrm{~mL}, 12.55 \mathrm{mmol}, 2.2 \mathrm{eq})$ in THF $(8 \mathrm{~mL}), 8 \mathrm{f}(1.00 \mathrm{~g}, 5.70 \mathrm{mmol})$ dissolved in THF (12 mL), and benzyl bromide ( $0.81 \mathrm{~mL}, 1.17 \mathrm{~g}, 6.84 \mathrm{mmol}, 1.2 \mathrm{eq})$ in THF $(2 \mathrm{~mL})$. The product $9 \mathbf{k}$ was obtained as colorless crystals $(0.95 \mathrm{~g}, 63 \%)$, m.p. $133-134{ }^{\circ} \mathrm{C}$ (hexane-EtOAc). ${ }^{1} \mathrm{H}-\mathrm{NMR}\left(400 \mathrm{MHz}, \mathrm{CDCl}_{3}\right) \delta 7.38(\mathrm{br} \mathrm{s}, 1 \mathrm{H}), 7.31(\mathrm{~d}, J=6.7 \mathrm{~Hz}, 1 \mathrm{H}), 7.12(\mathrm{dt}, J=7.7,1.2 \mathrm{~Hz}, 1 \mathrm{H})$, 
7.05-6.97 (m, 4H), $6.83(\mathrm{dd}, J=7.4,1.4 \mathrm{~Hz}, 2 \mathrm{H}), 6.61(\mathrm{~d}, J=7.7 \mathrm{~Hz}, 1 \mathrm{H}), 3.20(\mathrm{~d}, J=13.0 \mathrm{~Hz}, 1 \mathrm{H}), 3.17(\mathrm{~d}$, $J=13.0 \mathrm{~Hz}, 1 \mathrm{H}), 2.37(\mathrm{sp}, J=6.8 \mathrm{~Hz}, 1 \mathrm{H}), 1.12(\mathrm{~d}, J=6.9 \mathrm{~Hz}, 3 \mathrm{H}), 0.83(\mathrm{~d}, J=6.8 \mathrm{~Hz}, 3 \mathrm{H}) .{ }^{13} \mathrm{C}-\mathrm{NMR}$ $\left(150 \mathrm{MHz}, \mathrm{CDCl}_{3}\right) \delta 180.8,141.1,136.4,130.7,129.9,127.6,127.5,126.2,124.6,121.8,109.1,58.6,41.5$, 35.5, 17.8, 17.4. IR (KBr) $\vee 3299,1716,1678 \mathrm{~cm}^{-1}$. MS (ESI): $266.16[\mathrm{M}+\mathrm{H}]^{+}$. EA Calcd. for $\mathrm{C}_{18} \mathrm{H}_{19} \mathrm{NO}$ (235.36): C, 81.47\%; H, 7.22\%; N, 5.28\%. Found: C, 81.26\%; H, 7.16\%; N, 5.25\%.

\subsection{General Procedure III for the Synthesis of Compounds $\mathbf{2 1}$}

To a mixture of BuLi in hexane $(4.45 \mathrm{~mL}, 7.13 \mathrm{mmol}, 1.6 \mathrm{M})$ and THF $(4.00 \mathrm{~mL})$, the solution of the appropriate 3 -alkyloxindole $8 \mathbf{b}$ or $\mathbf{8 f}(2.85 \mathrm{mmol})$ in THF $(2 \mathrm{~mL})$ was added dropwise at $-78{ }^{\circ} \mathrm{C}$, under argon atmosphere. The acetone-dry ice bath was removed, the reaction mixture was allowed to warm to room temperature and the apparatus was opened to the air. The stirring was continued for further $2 \mathrm{~h}$, then the solvent was evaporated. The residue was taken up in water and extracted with EtOAc $(3 \times 15 \mathrm{~mL})$. The organic layer was dried over $\mathrm{MgSO}_{4}$ and evaporated. The solid residue was triturated in DCM $(2 \mathrm{~mL})$. The white solid was filtered and dried. Analytical samples were obtained by recrystallization from the mixture of hexane-EtOAc.

3-Hydroxy-3-isopropyl-1,3-dihydro-2H-indol-2-one (21a) [56]. This compound was prepared according to the general procedure III. The product 21a was obtained as colorless crystals (513 mg, 94\%), m.p. 170-172 ${ }^{\circ} \mathrm{C}$ (hexane-EtOAc), lit. [56] m.p. $45-50{ }^{\circ} \mathrm{C} .{ }^{1} \mathrm{H}-\mathrm{NMR}\left(400 \mathrm{MHz}, \mathrm{DMSO}-d_{6}\right) \delta 10.21$ (br s, 1H), 7.23-7.18 (m, 2H), $6.95(\mathrm{dt}, J=8.5,1.0 \mathrm{~Hz}, 1 \mathrm{H}), 6.79(\mathrm{~d}, J=7.7 \mathrm{~Hz}, 1 \mathrm{H}), 5.77(\mathrm{br} \mathrm{s}, 1 \mathrm{H}), 2.06$ $(\mathrm{sp}, J=6.9 \mathrm{~Hz}, 1 \mathrm{H}), 0.96(\mathrm{~d}, J=6.9 \mathrm{~Hz}, 3 \mathrm{H}), 0.63(\mathrm{~d}, J=6.8 \mathrm{~Hz}, 3 \mathrm{H}) .{ }^{13} \mathrm{C}-\mathrm{NMR}\left(100 \mathrm{MHz}, \mathrm{DMSO}-d_{6}\right) \delta$ 179.7, 142.4, 130.8, 128.9, 124.8, 121.5, 109.5, 78.5, 35.0, 16.4, 16.0. IR (KBr) v 3350, $1702 \mathrm{~cm}^{-1}$. MS (ESI): $191.88[\mathrm{M}+\mathrm{H}]^{+}$. Anal. Calcd. for $\mathrm{C}_{11} \mathrm{H}_{13} \mathrm{NO}_{2}$ (191.23): $\mathrm{C}, 69.09 \% ; \mathrm{H}, 6.85 \% ; \mathrm{N}, 7.32 \%$. Found: C, $68.99 \% ; \mathrm{H}, 6.62 \%$; N, $7.42 \%$.

3-Ethyl-3-hydroxy-1,3-dihydro-2H-indol-2-one (21b) [57]. This compound was prepared according to the general procedure III. The product $\mathbf{2 1 b}$ was obtained as colorless crystals ( $369 \mathrm{mg}, 73 \%$ ), m.p. 124-125 ${ }^{\circ} \mathrm{C}$ (hexane-EtOAc), lit. [48] m.p. $115-116{ }^{\circ} \mathrm{C}$.

5-Chloro-3,3-diethyl-1,3-dihydro-2H-indol-2-one (91). To a solution of $9 \mathrm{~d}(1.89 \mathrm{~g}, 10.00 \mathrm{mmol})$ in acetic acid $(20 \mathrm{~mL})$, sulfuryl chloride $(1.62 \mathrm{~mL}, 2.69 \mathrm{~g}, 20.00 \mathrm{mmol})$ was added dropwise at $10-15^{\circ} \mathrm{C}$. The reaction mixture was stirred at $10^{\circ} \mathrm{C}$ for 3 hours. The reaction mixture was poured onto ice-water $(50 \mathrm{~g})$ and stirred for one hour. The precipitate was filtered off, and washed with water until the $\mathrm{pH}$ was adjusted to 7 . The crude product 91 ( $2.09 \mathrm{~g}, 93 \%)$ was recrystallized from hexane-EtOAc to give 91 (1.64 $\mathrm{g}$, $73 \%$ ) as colorless crystals, m.p. $166-167^{\circ} \mathrm{C}$ (hexane-EtOAc). ${ }^{1} \mathrm{H}-\mathrm{NMR}\left(400 \mathrm{MHz}, \mathrm{CDCl}_{3}\right) \delta 9.33$ (br s, $1 \mathrm{H}), 7.19(\mathrm{dd}, J=8.2,2.1 \mathrm{~Hz}, 1 \mathrm{H}), 7.10(\mathrm{~d}, J=2.0 \mathrm{~Hz}, 1 \mathrm{H}), 6.88(\mathrm{~d}, J=8.2 \mathrm{~Hz}, 1 \mathrm{H}), 1.97-1.89(\mathrm{~m}, 2 \mathrm{H})$, 1.84-1.76 (m, 2H), $0.65(\mathrm{t}, J=7.4 \mathrm{~Hz}, 6 \mathrm{H}) .{ }^{13} \mathrm{C}-\mathrm{NMR}\left(100 \mathrm{MHz}, \mathrm{CDCl}_{3}\right) \delta 182.7,140.2,134.3,127.8,127.6$, 123.4, 110.6, 55.4, 30.6, 8.6. IR (KBr) v 3133, $1717 \mathrm{~cm}^{-1}$. MS (EI): 223 [M], 195, 194, 166, 159. EA Calcd. for $\mathrm{C}_{12} \mathrm{H}_{14} \mathrm{ClNO}$ (223.70): C, 64.43\%; H, 6.31\%; N, 7.32\%; Cl, 15.85\%. Found: C, 64.37\%; H, 6.32\%; $\mathrm{N}, 6.21 \% ; \mathrm{Cl}, 15.56 \%$.

5-Bromo-3,3-diethyl-1,3-dihydro-2H-indol-2-one (9m) [32]. To a solution of $9 \mathbf{d}(0.95 \mathrm{~g}, 5.00 \mathrm{mmol})$ in dioxane-water $(10 \mathrm{~mL}-5 \mathrm{~mL})$, a mixture of bromine $(0.26 \mathrm{~mL}, 0.80 \mathrm{~g}, 5.00 \mathrm{mmol})$ and potassium bromide $(1.19 \mathrm{~g}, 10.00 \mathrm{mmol})$ in water $(10 \mathrm{~mL})$ was added dropwise at $90^{\circ} \mathrm{C}$. After $10 \mathrm{~min}$, water $(5 \mathrm{~mL})$ was added dropwise at $90^{\circ} \mathrm{C}$ and crystals were precipitated. The reaction mixture was cooled with an ice bath, filtered off and washed with water and hexane. The product $9 \mathrm{~m}$ was obtained as colorless crystals $(1.26$ g, $94 \%)$, m.p. $165-166{ }^{\circ} \mathrm{C}$ (hexane-EtOAc), lit. [32] m.p. $164-165^{\circ} \mathrm{C} .{ }^{1} \mathrm{H}-\mathrm{NMR}(400 \mathrm{MHz}$, $\left.\mathrm{CDCl}_{3}\right) \delta 8.76(\mathrm{br} \mathrm{s}, 1 \mathrm{H}), 7.32(\mathrm{dd}, J=8.2,2.0 \mathrm{~Hz}, 1 \mathrm{H}), 7.21(\mathrm{~d}, J=2.0 \mathrm{~Hz}, 1 \mathrm{H}), 6.80(\mathrm{~d}, J=8.2 \mathrm{~Hz}, 1 \mathrm{H})$, $1.96-1.86(\mathrm{~m}, 2 \mathrm{H}), 1.81-1.71(\mathrm{~m}, 2 \mathrm{H}), 0.63(\mathrm{t}, J=7.4 \mathrm{~Hz}, 6 \mathrm{H}) .{ }^{13} \mathrm{C}-\mathrm{NMR}\left(100 \mathrm{MHz}, \mathrm{CDCl}_{3}\right) \delta 182.6,140.7$, $134.7,130.5,126.2,115.1,111.2,55.4,30.6,8.6 . \mathrm{IR}(\mathrm{KBr}) \vee 3133,1719,1203,812 \mathrm{~cm}^{-1}$. MS (EI): 267 [M], $239,160,159$. EA Calcd. for $\mathrm{C}_{12} \mathrm{H}_{14} \mathrm{BrNO}$ (268.15): C, 53.75\%; H, 5.26\%; N, 5.22\%; Br, 29.80\%. Found: C, $54.00 \% ; \mathrm{H}, 5.40 \% ; \mathrm{N}, 5.11 \% ; \mathrm{Cl}, 29.37 \%$. 
3,3-Diethyl-5-nitro-1,3-dihydro-2H-indol-2-one (9n) [5]. To a solution of $9 \mathrm{~d}$ (11.06 g, $61.0 \mathrm{mmol})$ in cc. sulfuric acid ( $200 \mathrm{~mL}, 368 \mathrm{~g}, 3.75 \mathrm{~mol})$, cc. nitric acid $(2.6 \mathrm{~mL}, 3.93 \mathrm{~g}, 62.0 \mathrm{mmol})$ was added dropwise at $0{ }^{\circ} \mathrm{C}$, the stirring was continued at room temperature for 2 hours. The precipitate was filtered off, washed with water until the $\mathrm{pH}$ was adjusted to 7 and dried. The product $9 \mathbf{n}$ was obtained as pale brown crystals $(12.40 \mathrm{~g}, 85 \%)$, m.p. $174-176{ }^{\circ} \mathrm{C}$ (EtOAc), lit. [5] m.p. $174-176{ }^{\circ} \mathrm{C} .{ }^{1} \mathrm{H}-\mathrm{NMR}(400 \mathrm{MHz}$, DMSO-d $\left.d_{6}\right) \delta 11.08$ (br s, 1H), 8.20-8.14 (m, 2H), 7.05-7.03 (m, 1H), 1.94-1.89 (m, 2H), 1.79-1.73 (m, 2H), $0.51(\mathrm{t}, J=7.4 \mathrm{~Hz}, 6 \mathrm{H}) .{ }^{13} \mathrm{C}-\mathrm{NMR}\left(100 \mathrm{MHz}, \mathrm{DMSO}-d_{6}\right) \delta 181.3,149.4,142.5,133.3,125.4,119.1,109.3$, 54.4, 29.8, 8.6. IR $(\mathrm{KBr}) \vee 1729,1340 \mathrm{~cm}^{-1}$. MS (ESI): $233.15(\mathrm{M}-\mathrm{H})^{-}$. EA Calcd. for $\mathrm{C}_{12} \mathrm{H}_{14} \mathrm{~N}_{2} \mathrm{O}_{3}$ (234.26): C, 61.53\%; H, 6.02\%; N, 11.96\%. Found: C, 61.18\%; H, 5.93\%; N, $12.01 \%$.

3,3-Diethyl-2-oxo-2,3-dihydro-1H-indole-5-sulfonyl chloride (9o). To sulfurochloridic acid ( $20 \mathrm{~mL}, 35.0 \mathrm{~g}$, $300.0 \mathrm{mmol}), 9 \mathrm{~d}(4.75 \mathrm{~g}, 25.0 \mathrm{mmol})$ was added at $15-20^{\circ} \mathrm{C}$, then the reaction mixture was heated at $60{ }^{\circ} \mathrm{C}$ for one hour. After cooling to room temperature the reaction mixture was added dropwise to ice. The precipitate was filtered off, washed with water until the $\mathrm{pH}$ was adjusted to 7 , then it was washed with hexane and dried. The product 90 was obtained as off-white crystals $(6.62 \mathrm{~g}, 98 \%)$, m.p. 186-188 ${ }^{\circ} \mathrm{C}$ (EtOAc). ${ }^{1} \mathrm{H}-\mathrm{NMR}\left(600 \mathrm{MHz}, \mathrm{CDCl}_{3}\right) \delta 9.09$ (br s, $\left.1 \mathrm{H}\right), 7.98(\mathrm{dd}, J=8.4,2.0 \mathrm{~Hz}, 1 \mathrm{H}), 7.78$ $(\mathrm{d}, J=1.9 \mathrm{~Hz}, 1 \mathrm{H}), 7.13(\mathrm{~d}, J=8.3 \mathrm{~Hz}, 1 \mathrm{H}), 2.04-1.98(\mathrm{~m}, 2 \mathrm{H}), 1.93-1.77(\mathrm{~m}, 2 \mathrm{H}), 0.68(\mathrm{t}, J=7.4 \mathrm{~Hz}, 6 \mathrm{H})$. ${ }^{13} \mathrm{C}-\mathrm{NMR}\left(150 \mathrm{MHz}, \mathrm{CDCl}_{3}\right) \delta 182.3,147.7,138.3,134.0,128.7,122.0,109.8,55.3,30.5,8.7 . \mathrm{IR}(\mathrm{KBr}) v$ 1729, 1366, $1175 \mathrm{~cm}^{-1}$. MS (EI): 287 [M], 259, 189, 161, 160, 159, 132, 130. EA Calcd. for $\mathrm{C}_{12} \mathrm{H}_{14} \mathrm{ClNO}_{3} \mathrm{~S}$ (287.76): C, $50.09 \%$; H, 4.90\%; N, 4.87\%; S, $11.14 \%$; Cl, $12.32 \%$. Found: C, $49.98 \%$; H, $4.93 \% ; \mathrm{N}, 4.82 \%$; $\mathrm{S}, 10.86 \% ; \mathrm{Cl}, 12.15 \%$.

5-Amino-3,3-diethyl-1,3-dihydro-2H-indol-2-one (9p) [5]. To a solution of $9 \mathbf{n}(800 \mathrm{mg}, 3.42 \mathrm{mmol}$ ) in methanol $(10 \mathrm{~mL})$, activated palladium on charcoal $(95 \mathrm{mg}, 0.80 \mathrm{mmol}, 10 \%)$ was added and the reaction mixture was placed into an autoclave (volume $70 \mathrm{~mL}$ ). It was flushed with nitrogen, charged with hydrogen (20 bar) and heated to $70{ }^{\circ} \mathrm{C}$ while stirring. After $7 \mathrm{~h}$ the mixture was cooled to room temperature, filtered and the solvent was evaporated in vacuo. The residue was triturated in hexane, filtered off and dried. The product $9 \mathrm{p}$ was obtained as off-white crystals $(610 \mathrm{mg}, 87 \%), \mathrm{m} . \mathrm{p}$. 189-190 ${ }^{\circ} \mathrm{C}$ (EtOH), lit. [5] m.p. 188-190 ${ }^{\circ} \mathrm{C} .{ }^{1} \mathrm{H}-\mathrm{NMR}\left(400 \mathrm{MHz}, \mathrm{DMSO}-d_{6}\right) \delta 9.89$ (br s, $\left.1 \mathrm{H}\right), 6.52$ $(\mathrm{d}, J=8.1 \mathrm{~Hz}, 1 \mathrm{H}), 6.44(\mathrm{~d}, J=2.2 \mathrm{~Hz}, 1 \mathrm{H}), 6.38(\mathrm{dd}, J=8.1,2.2 \mathrm{~Hz}, 1 \mathrm{H}), 4.66(\mathrm{br} \mathrm{s}, 2 \mathrm{H}), 1.69-1.58$ $(\mathrm{m}, 4 \mathrm{H}), 0.51(\mathrm{t}, J=7.3 \mathrm{~Hz}, 6 \mathrm{H}) .{ }^{13} \mathrm{C}-\mathrm{NMR}\left(100 \mathrm{MHz}, \mathrm{DMSO}-d_{6}\right) \delta 180.3,143.7,132.9,132.6,112.7,110.1$, 109.4, 54.1, 30.2, 8.8. IR (KBr) v 2963, 1684, $1496 \mathrm{~cm}^{-1}$. MS: $204(\mathrm{M}), 175,157,147,132$. EA Calcd. for $\mathrm{C}_{12} \mathrm{H}_{16} \mathrm{~N}_{2} \mathrm{O}$ (204.27): $\mathrm{C}, 70.56 \% ; \mathrm{H}, 7.90 \%$;, $13.71 \%$. Found: $\mathrm{C}, 70.05 \% ; \mathrm{H}, 7.68 \% ; \mathrm{N}, 13.65 \%$.

3,3-Diethyl-2-oxo-2,3-dihydro-1H-indole-5-sulfonamide (9q). To a solution of $\mathbf{9 o}$ (1.35 g, $5.00 \mathrm{mmol})$ in $\mathrm{EtOH}(50 \mathrm{~mL})$, ammonium hydroxide solution $(5 \mathrm{~mL}, 74.0 \mathrm{mmol}, 25 \mathrm{w} / \mathrm{w} \%)$ was added dropwise at $0{ }^{\circ} \mathrm{C}$. The reaction mixture was stirred at room temperature for one hour. The volatile compounds were removed in vacuo and the crude product was recrystallized from acetic acid $(25 \mathrm{~mL})$ to give $\mathbf{9 q}$ $(0.80 \mathrm{~g}, 60 \%)$ as pale yellow crystals, m.p. $189-190{ }^{\circ} \mathrm{C}(\mathrm{EtOH}) .{ }^{1} \mathrm{H}-\mathrm{NMR}\left(400 \mathrm{MHz}\right.$, DMSO- $\left.d_{6}\right) \delta 10.76$ (br s, $1 \mathrm{H}), 7.69(\mathrm{dd}, J=8.1,1.8 \mathrm{~Hz}, 1 \mathrm{H}), 7.64(\mathrm{~d}, J=1.8 \mathrm{~Hz}, 1 \mathrm{H}), 7.20(\mathrm{~s}, 2 \mathrm{H}), 6.98(\mathrm{~d}, J=8.2 \mathrm{~Hz}, 1 \mathrm{H})$, $1.83-1.71(\mathrm{~m}, 4 \mathrm{H}), 0.53(\mathrm{t}, J=7.3 \mathrm{~Hz}, 6 \mathrm{H}) .{ }^{13} \mathrm{C}-\mathrm{NMR}\left(100 \mathrm{MHz}, \mathrm{DMSO}-d_{6}\right) \delta 181.0,145.9,137.6,132.5$, 126.5, 120.8, 108.9, 54.1, 29.9, 8.7. IR (KBr) v 3334, 1725, 1328, $1172 \mathrm{~cm}^{-1}$. MS (EI): 268 [M], 240, 159, 130. Anal. Calcd. for $\mathrm{C}_{12} \mathrm{H}_{16} \mathrm{~N}_{2} \mathrm{O}_{3} \mathrm{~S}$ (268.33): C, 53.71\%; H, 6.01\%; N, $10.44 \%$;, $11.95 \%$. Found: $\mathrm{C}, 53.59 \%$; $\mathrm{H}, 6.02 \%$; N $10.37 \%$; S, $11.75 \%$.

N-tert-Butyl-3,3-diethyl-2-oxo-2,3-dihydro-1H-indole-5-sulfonamide (9r). To a mixture of 90 (2.90 g, $10.10 \mathrm{mmol})$ and sodium carbonate $(1.20 \mathrm{~g}, 11.32 \mathrm{mmol})$ in THF $(100 \mathrm{~mL})$, tert-butylamine $(2.4 \mathrm{~mL}$, $1.68 \mathrm{~g}, 22.98 \mathrm{mmol}$ ) was added at room temperature. The reaction mixture was refluxed for $7 \mathrm{~h}$, then the volatile compounds were removed in vacuo at $40^{\circ} \mathrm{C}$ and hydrochloric acid $(30 \mathrm{~mL}, 1.0 \mathrm{M})$ was added. The aqueous layer was extracted with EtOAc $(3 \times 15 \mathrm{~mL})$, the combined organic layer was dried over $\mathrm{MgSO}_{4}$ and evaporated. The solid residue was triturated in DEE $(5 \mathrm{~mL})$, filtered off and dried. The product 9r was obtained as colorless crystals ( 2.00 g, 61\%), m.p. $202-203{ }^{\circ} \mathrm{C}(\mathrm{EtOH}) .{ }^{1} \mathrm{H}-\mathrm{NMR}$ 
(400 MHz, CD 3 CN) $\delta 8.7$ (br s, 1H), $7.72(\mathrm{dd}, J=8.2,2.0 \mathrm{~Hz}, 1 \mathrm{H}), 7.64(\mathrm{dd}, J=1.8,0.5 \mathrm{~Hz}, 1 \mathrm{H}), 7.01$ (dd, $J=8.2,0.3 \mathrm{~Hz}, 1 \mathrm{H}), 5.47(\mathrm{~s}, 1 \mathrm{H}), 1.83(\mathrm{q}, J=7.5 \mathrm{~Hz}, 4 \mathrm{H}), 1.13(\mathrm{~s}, 9 \mathrm{H}), 0.56(\mathrm{t}, J=7.5 \mathrm{~Hz}, 6 \mathrm{H}) .{ }^{13} \mathrm{C}-\mathrm{NMR}$ $\left(100 \mathrm{MHz}, \mathrm{CD}_{3} \mathrm{CN}\right) \delta 182.0,146.9,138.4,134.1,128.6,123.0,110.1,55.6,54.9,31.3,30.3,9.00 . \mathrm{IR}(\mathrm{KBr})$ $v$ 3231, 1718, 1299, $1144 \mathrm{~cm}^{-1}$. MS (EI): 324 [M], 309, 252, 204, 188, 159. EA Calcd. for $\mathrm{C}_{16} \mathrm{H}_{24} \mathrm{~N}_{2} \mathrm{O}_{3} \mathrm{~S}$ (324.44): C, 59.23\%; H, 7.46\%; N, 8.63\%; S, 9.88\%. Found: C, 58.91\%; H, 7.44\%; N, 8.75\%; S, 9.69\%.

3,3-Diethyl-5-(morpholin-4-ylsulfonyl)-1,3-dihydro-2H-indol-2-one (9s). To a mixture of 9o (2.88 g, $10.0 \mathrm{mmol})$ and sodium carbonate $(1.59 \mathrm{~g}, 15.0 \mathrm{mmol})$ in THF $(100 \mathrm{~mL})$, morpholine $(6.00 \mathrm{~mL}, 6.06 \mathrm{~g}$, $69.6 \mathrm{mmol}$ ) was added at room temperature. The reaction mixture was refluxed for $5 \mathrm{~h}$. The solvent was removed in vacuo at $40^{\circ} \mathrm{C}$ and hydrochloric acid $(30 \mathrm{~mL}, 1.0 \mathrm{M})$ was added. The aqueous layer was extracted with EtOAc $(3 \times 15 \mathrm{~mL})$. The combined organic layer was dried over $\mathrm{MgSO}_{4}$ and evaporated. The solid residue was triturated in DEE $(5 \mathrm{~mL})$, filtered off and dried. The product $9 \mathrm{~s}$ was obtained as colorless crystals $(2.58 \mathrm{~g}, 76 \%)$, m.p. $202-203{ }^{\circ} \mathrm{C}(\mathrm{EtOH}) .{ }^{1} \mathrm{H}-\mathrm{NMR}\left(400 \mathrm{MHz}, \mathrm{CDCl}_{3}\right) \delta$ 8.78 (br s, $1 \mathrm{H}), 7.67(\mathrm{dd}, J=8.2,1.8 \mathrm{~Hz}, 1 \mathrm{H}), 7.51(\mathrm{~d}, J=1.7 \mathrm{~Hz}, 1 \mathrm{H}), 7.08(\mathrm{~d}, J=8.2 \mathrm{~Hz}, 1 \mathrm{H}), 3.78-3.75$ $(\mathrm{m}, 4 \mathrm{H}), 3.00-2.97(\mathrm{~m}, 4 \mathrm{H}), 2.02-1.96(\mathrm{~m}, 2 \mathrm{H}), 1.88-1.83(\mathrm{~m}, 2 \mathrm{H}), 0.65(\mathrm{t}, J=7.4 \mathrm{~Hz}, 6 \mathrm{H}) .{ }^{13} \mathrm{C}-\mathrm{NMR}$ $\left(100 \mathrm{MHz}, \mathrm{CDCl}_{3}\right) \delta 182.1,145.8,133.5,128.7$ (128.68, 128. 67), 122.8, 109.6, 66.1, 55.0, 46.0, 30.6, 8.7. IR $(\mathrm{KBr}) \vee 1741,1347,1164 \mathrm{~cm}^{-1}$. MS (ESI): $339.14[\mathrm{M}+\mathrm{H}]^{+}$. Anal. Calcd. for $\mathrm{C}_{16} \mathrm{H}_{22} \mathrm{~N}_{2} \mathrm{O}_{4} \mathrm{~S}(338.42)$ : C, 56.79\%; H, 6.55\%; N, 8.28\%; S, 9.47\%. Found: C, 56.78\%; H, 6.49\%; N, 8.34\%; S, 9.62\%.

5,7-Dichloro-3,3-diethyl-1,3-dihydro-2H-indol-2-one (9t). To a solution of $9 d$ (3.78 g, $20.0 \mathrm{mmol})$ in acetic acid $(40 \mathrm{~mL})$, sulfuryl chloride $(4.80 \mathrm{~mL}, 8.09 \mathrm{~g}, 60.0 \mathrm{mmol})$ was added dropwise at room temperature. The mixture was heated to $60{ }^{\circ} \mathrm{C}$ for 4 hours. It was cooled to room temperature, then the reaction mixture was poured onto ice-water $(50 \mathrm{~g})$. The precipitate thus obtained was filtered off, washed with water until the $\mathrm{pH}$ was adjusted to 7, then it was washed with hexane and dried to give $9 \mathrm{t}(5.00 \mathrm{~g}, 97 \%)$. The crude product $9 \mathrm{t}$ was recrystallized from water $(80 \mathrm{~mL})$ and $\mathrm{EtOH}(120 \mathrm{~mL})$ to give $9 \mathrm{t}(3.48 \mathrm{~g}$, $13.48 \mathrm{mmol}, 67 \%)$ as colorless crystals, m.p. $177-178^{\circ} \mathrm{C}$ (water-EtOH). ${ }^{1} \mathrm{H}-\mathrm{NMR}\left(400 \mathrm{MHz}, \mathrm{CDCl}_{3}\right) \delta$ 8.08 (br s, 1H), $7.23(\mathrm{~d}, J=1.9 \mathrm{~Hz}, 1 \mathrm{H}), 7.01(\mathrm{~d}, J=1.8 \mathrm{~Hz}, 1 \mathrm{H}), 2.00-1.91(\mathrm{~m}, 2 \mathrm{H}), 1.82-1.64(\mathrm{~m}, 2 \mathrm{H}), 0.66$ $(\mathrm{t}, J=7.4 \mathrm{~Hz}, 6 \mathrm{H}) .{ }^{13} \mathrm{C}-\mathrm{NMR}\left(100 \mathrm{MHz} \mathrm{CDCl}_{3}\right) \delta 180.4,137.8,135.2,128.1,127.4,122.0,115.1,56.5,30.7$, 8.7. IR (KBr) v 3183, $1725 \mathrm{~cm}^{-1}$. MS (EI): 259, 257 [M], 231, 230, 229, 228, 214, 200, 193, 165, 164. EA Calcd. for $\mathrm{C}_{12} \mathrm{H}_{13} \mathrm{Cl}_{2} \mathrm{NO}$ (258.14): C, 55.83\%; H, 5.08\%; N, 5.43\%, Cl, 27.47. Found: C, 55.76\%; H, 5.07\%; $\mathrm{N}, 5.41 \% ; \mathrm{Cl}, 27.46 \%$.

5,7-Dichloro-3,3-diethyl-6-fluoro-1,3-dihydro-2H-indol-2-one (9u). To a solution of $\mathbf{9 g}(1.04 \mathrm{~g}, 5.0 \mathrm{mmol})$ in acetic acid $(30 \mathrm{~mL})$, sulfuryl chloride $(2.00 \mathrm{~mL}, 3.34 \mathrm{~g}, 25.0 \mathrm{mmol})$ was added dropwise at room temperature. The mixture was heated to $70-80^{\circ} \mathrm{C}$ for $1 \mathrm{~h}$. It was cooled to room temperature, then the reaction mixture was poured onto ice-water $(30 \mathrm{~g})$. The precipitate thus obtained was filtered off, washed with water until the $\mathrm{pH}$ was adjusted to 7 , then it was washed with hexane and dried. The product $9 \mathbf{u}$ was obtained as colorless crystals $(1.20 \mathrm{~g}, 87 \%)$, m.p. $192-193{ }^{\circ} \mathrm{C}$ (hexane-EtOAc). ${ }^{1} \mathrm{H}-\mathrm{NMR}\left(400 \mathrm{MHz}, \mathrm{CDCl}_{3}\right) \delta 9.05$ (br s, 1H), 7.05 (d, $\left.J=6.3 \mathrm{~Hz}, 1 \mathrm{H}\right), 2.00-1.94(\mathrm{~m}, 2 \mathrm{H}), 1.81-1.74$ $(\mathrm{m}, 2 \mathrm{H}), 0.67(\mathrm{t}, J=7.4 \mathrm{~Hz}, 6 \mathrm{H}) .{ }^{13} \mathrm{C}-\mathrm{NMR}\left(100 \mathrm{MHz}, \mathrm{CDCl}_{3}\right) \delta 181.4,153.5(\mathrm{~d}, J=248.3 \mathrm{~Hz}), 139.5$ $(\mathrm{d}, J=2.7 \mathrm{~Hz}), 128.6(\mathrm{~d}, J=4.2 \mathrm{~Hz}), 122.7,115.0(\mathrm{~d}, J=18.7 \mathrm{~Hz}), 104.6(\mathrm{~d}, J=22.9 \mathrm{~Hz}), 56.2,30.6,8.6$. IR $(\mathrm{KBr}) \vee 3085,1726,1189,770 \mathrm{~cm}^{-1}$. MS (EI): 277, 275 [M], 248, 246, 218, 211, 183. Anal. Calcd. for $\mathrm{C}_{12} \mathrm{H}_{12} \mathrm{Cl}_{2} \mathrm{FNO}$ (276.14): C, 52.20\%; H, 4.38\%; N, 5.07\%; Cl, 25.68\%. Found: C, 52.06\%; H, 4.44\%; $\mathrm{N}, 5.16 \% ; \mathrm{Cl}, 25.79 \%$.

\section{Conclusions}

A systematic study of regioselective 3-alkylation reaction of N-unprotected-3-monosubstituted oxindoles was carried out after summarizing the literature of the numerous, albeit sporadic, precedents giving mostly unsatisfactory results. We have now elaborated an optimized method for the 3-alkylation of N-unsubstituted 3-alkyloxindoles by applying butyllithium as the base and alkyl bromides as the alkylating agents. The method has been extended to various alkyl groups in position 3 and various substituents on the aromatic ring. Introduction of new substituents into the aromatic ring 
of 3,3-diethyloxindole is disclosed. The formation of 3-hydroxylated side-products was investigated and the targeted synthesis of these compounds is also described. Owing to the presence of the unsubstituted nitrogen atom N1 in the title products (and the 3-hydroxy moiety in certain compounds), further functionalizations can also be carried out, thereby making these compounds valuable building blocks in synthetic organic or medicinal chemistry.

Author Contributions: E. K. performed the experiments and compiled the Experimental Section; G. S. and B. V. conceived and designed the experiments, and wrote the further chapters of the paper.

Conflicts of Interest: The authors declare no conflict of interest.

\section{References and Notes}

1. Oxindole derivatives reaching human Phase III clinical trials are as follows: Tenidap, famitinib, linopirdine, flindokalner, satavaptan.

2. Oxindole derivatives reaching human Phase II clinical trials are as follows: Aplindore, cipargamin, icopezil maleate, amcasertib, adibendan, funapide, NS-1209, semaxanib, indolidan.

3. Oxindole derivatives reaching human Phase I clinical trials are as follows: SNAP-37889, PF-03382792, CP-126998, henatinib, BI-847325, CFI-400945, tafetinib, XEN-401, SSR-126768A, T-0632, DS-3032b.

4. Nozoye, T.; Nakai, T.; Kubo, A. (E)- and (Z)-2-Oxoindolin-3-ethylidenes. Chem. Pharm. Bull. 1977, 25, 196-198. [CrossRef]

5. Mertens, A.; Müller-Beckmann, B.; Kampe, W.; Hölck, J.-P.; von der Saal, W. Nonsteroidal cardiotonics. 1. 2-Pyridyl-6,7-dihydro-3H,5H-pyrrolo[2,3-f]benzimidazol-6-ones, a novel class of cardiotonic agents. J. Med. Chem. 1987, 30, 1279-1287. [CrossRef] [PubMed]

6. Tacconi, G.; Maggi, L.D.; Righetti, P.; Desimoni, G.; Azzolina, O.; Ghislandi, V. (Z)- and (E)-3-Alkylidene-1,3-dihydroindol-2-ones. Influence of configuration on the transmission of the inductive effect to the carbonyl group. J. Chem. Soc., Perkin Trans. 2 1976, 150-154. [CrossRef]

7. Wenkert, E.; Bringi, N.V. A new procedure for forming carbon-carbon bonds. J. Am. Chem. Soc. 1958, 80, 5575-5576. [CrossRef]

8. Wenkert, E.; Bringi, N.V.; Choulett, H.E. Raney nickel-induced alkylation reactions. Acta Chem. Scand. Ser. B 1982, 36, 348-350. [CrossRef]

9. Volk, B.; Mezei, T.; Simig, G. Raney nickel-induced 3-alkylation of oxindole with alcohols and diols. Synthesis 2002, 595-597. [CrossRef]

10. Gruda, I. Formation of N- and C-substituted derivatives during alkylation of indol-2(3H)-one. Can. J. Chem. 1972, 50, 18-23. [CrossRef]

11. Reisch, J.; Müller, M.; Labitzke, H. Synthetic pathways for 3-substituted indol-2-ones. Arch. Pharm. 1984, 317, 639-646. [CrossRef]

12. Horner, L. Syntheses in the oxindole series. Liebigs Ann. Chem. 1941, 548, 117-146. [CrossRef]

13. Wenkert, E.; Bernstein, B.S.; Udelhofen, J.H. A novel conversion of derivatives of oxindoles to indoles. J. Am. Chem. Soc. 1958, 80, 4899-4903. [CrossRef]

14. Shaun, J.; Tetsuro, K.; Katsura, T.; Tsuyoshi, H.; Yasufumi, U. Carbostyril derivative 5-HT $\mathrm{HT}_{1 \mathrm{a}}$ receptor subtype agonist for treatment of central nervous system disorders. US 2011195954 U.S. Pat. Appl., Nov 21, 2002. Chem. Abstr. 2002, 137, 363096.

15. Karig, G.; Ford, M.J.; Siegel, K.; Schnatterer, S. Method for producing N-sulfonyl-substituted oxindoles. US 2015133660 PCT Intern. Pat. Appl., May 14, 2015. Chem. Abstr. 2012, 157, 165628.

16. Cook, B.N.; Huber, J.D.; Hughes, R.O.; Kirrane, T.M., Jr.; Lasota, C.; Li, X.; Liang, S.; Mugge, I.A.; Zhang, Q. Preparation of bicyclic compounds as modulators of retinoid-related orphan receptor $\gamma \mathrm{t}$ (ROR $\gamma \mathrm{t}$ or RORc). WO 2015035032 PCT Intern. Pat. Appl., Mar 12, 2015. Chem. Abstr. 2015, 162, 425159.

17. Alkylation of a 3-(substituted phenyl)oxindole and related compounds with $\alpha, \omega$-iodochloroalkanes with $t$-BuOK in DMF is described with undisclosed yields in: Foulon, L.; Goullieux, L.; Pouzet, B.; Le Serradeil, G.; Claudine, V.G. Novel 3-aminoalkyl-1,3-dihydro-2H-indol-2-one derivatives, preparation thereof and therapeutic use thereof. US 2011059955 U.S. Pat. Appl., Mar 10, 2011, also published as WO 2009115685 PCT Intern. Pat. Appl., Sep 24, 2009. Chem. Abstr. 2009, 151, 403108. 
18. Alkylation of 3-phenyloxindole with $t$-BuOK and 1,2-dibromoethane in THF is described in $53 \%$ yield in: Kato, K.; Doi, T.; Sugiura, Y.; Kawada, M. Preparation of 3-[2-(4-arylazino)ethyl]-2-indolones and analogs as antiincontinence agents. WO 9802432 PCT Intern. Pat. Appl., Jan 22, 1998. Chem. Abstr. 1998, 128, 140729.

19. 3-Methyl-4-methoxyoxindole was 3-methylated with potassium bis(trimethylsilyl)amide and methyliodide in THF to give the product in 58\% yield after laborious work-up, see: Jesudason, C.D.; Sall, D.J.; Stevens, F.C.; Werner, J.A. Preparation of oxindolyloxypropanolamines as $\beta 3$ adrenergic receptor agonists. WO 0238543 PCT Intern. Pat. Appl., May 16, 2002. Chem. Abstr. 2002, 136, 369605.

20. Reaction of 5-chloro-3-(4-methoxyphenyl)oxindole with benzyl bromide in the presence of $\mathrm{K}_{2} \mathrm{CO}_{3}$ and $\mathrm{KI}$ in acetone, subsequent work-up by flash chromatography, and preparation of several analogous derivatives in low to moderate yields in a similar manner are described in: Kin-Chun, L.; Sung-Sau, S.; Jing, Z.; Zhuming, Z. Preparation of oxindoles as inhibitors of MDM2-p53 interaction for the treatment of cancer. WO 2006136606 PCT Intern. Pat. Appl., Dec 28, 2006. Chem. Abstr. 2006, 146, 100555.

21. Reaction of 5-(3,5-dimethylisoxazol-4-yl)-3-phenyloxindole with ethyl bromoacetate in the presence of $\mathrm{K}_{2} \mathrm{CO}_{3}$ and $\mathrm{KI}$ in acetone, and reaction of 5-(3,5-dimethylisoxazol-4-yl)-3-phenyloxindole with 3-bromopropan-1-ol in the presence of $\mathrm{K}_{2} \mathrm{CO}_{3}$ and $\mathrm{KI}$ in THF, and subsequent work-up by flash chromatography are disclosed in $60 \%$ and $41 \%$ yields, respectively, in: Bo, R.; Changyou, Z.; Hexiang, W. 5-(3,5-Dimethylisoxazol-4-yl)indolin-2-ones as BRD4 inhibitors and their preparation and use for the treatment of cancer. WO 2014173241 PCT Intern. Pat. Appl., Oct 30, 2014. Chem. Abstr. 2014, 161, 664198.

22. 3-(Substituted phenyl) or 3-methyloxindoles, eventually substituted on the aromatic ring of the oxindole skeleton, are alkylated with $\mathrm{K}_{2} \mathrm{CO}_{3}$ and variously substituted benzyl bromides in DMA. Chromatographic purification is necessary, yields are not disclosed, see: Wilson, J.E.; Kurukulasuriya, R.; Reibarkh, M.; Reiter, M.; Zwicker, A.; Zhao, K.; Zhang, F.; Anand, R.; Colandrea, V.J.; Cumiskey, A.-M.; Crespo, A.; Duffy, R.A.; Murphy, B.A.; Mitra, K.; Johns, D.G.; Duffy, J.L.; Vachal, P. Discovery of novel indoline cholesterol ester transfer protein inhibitors (CETP) through a structure-guided approach. ACS Med. Chem. Lett. 2016, 7, 261-265. [CrossRef] [PubMed]

23. 3-Arlyoxindoles are alkylated with $\mathrm{K}_{2} \mathrm{CO}_{3}$ and substituted benzyl bromides in DMA. The products are obtained after chromatography in unknown yields, see: Wilson, J.E.; Vachal, P.; Kurukulasuriya, R. 3,3'-Disubstituted indolines as inhibitors of cholesterol ester transfer protein. WO 2015054088 PCT Intern. Pat. Appl., Apr 16, 2015. Chem. Abstr. 2015, 162, 544611.

24. Reaction of 6-bromo-3-methyloxindole with methyl bromoacetate and allyl bromide in the presence of $\mathrm{Cs}_{2} \mathrm{CO}_{3}$ in DMF is described, after purification by flash chromatography, in $71 \%$ and $51 \%$ yields, respectively, in: Chen, G.; Cushing, T.D.; Fisher, B.; He, X.; Li, K.; Li, Z.; McGee, L.R.; Pattaropong, V.; Faulder, P.; Seganish, J.L.; et al. Alkynyl alcohols as kinase inhibitors and their preparation, pharmaceutical compositions and use in the treatment of inflammation and inflammatory disorders. WO 2009158011 PCT Intern. Pat. Appl., Dec 30, 2009. Chem. Abstr. 2009, 152, 119631.

25. Kende, A.S.; Hodges, J.C. Regioselective C-3 alkylations of oxindole dianion. Synth. Commun. 1982, 12, 1-10. [CrossRef]

26. Fensome, A.; Mccomas, C.C.; Melenski, E.G.; Marella, M.A.; Wrobel, J.E. Progesterone receptor modulators comprising pyrrole-oxindole derivatives and uses thereof. US 2006030615 U.S. Pat. Appl., Feb 9, 2006. Chem. Abstr. 2006, 144, 192104.

27. Brittain, W.D.G.; Buckley, B.R.; Fossey, J.S. Kinetic resolution of alkyne-substituted quaternary oxindoles via copper catalysed azide-alkyne cycloadditions. Chem. Commun. 2015, 51, 17217-17220. [CrossRef] [PubMed]

28. Li, Q.; Woods, K.W.; Zhu, G.-D.; Fischer, J.P.; Gong, J.; Li, T.; Gandhi, V.; Thomas, S.A.; Packard, G.; Song, X.; et al. Preparation of pyridine derivatives as protein kinase inhibitors. WO 03051366 PCT Intern. Pat. Appl., Oct 2, 2003. Chem. Abstr. 2003, 139, 69152.

29. For the introduction of identical alkyl groups (Me, Et, Bn) in position 3 of 4-methoxyoxindole (2 eq BuLi, TMEDA, THF), see: Stevens, F.C.; Bloomquist, W.E.; Borel, A.G.; Cohen, M.L.; Droste, C.A.; Heiman, M.L.; Kriauciunas, A.; Sall, D.J.; Tinsley, F.C.; Jesudason, C.D. Potent oxindole based human $\beta 3$ adrenergic receptor agonists. Bioorg. Med. Chem. Lett. 2007, 17, 6270-6273. [CrossRef] [PubMed]

30. 3-Alkylation (benzylation) of 3-(substituted phenyl)oxindoles with BuLi (2.2 eq), TMEDA (2.2 eq) and alkylating agent (2.2 eq) with chromatographic work-up is described in: Christensen, M.K.; Bjoerkling, F. Preparation of 3-(4-hydroxyphenyl)-indolin-2-ones for the treatment of cancer. WO 2008129075 PCT Intern. Pat. Appl., Oct 30, 2008. Chem. Abstr. 2008, 149, 513691. 
31. 3-Ethylation of 3-ethyloxindole with BuLi (2.0 eq), TMEDA (2.0 eq) and EtI (1.0 eq) in 45\% yield is described in: Grubb, G.S.; Zhi, L.; Jones, T.K.; Tegley, C.M.; Fensome, A.; Miller, L.L.; Ullrich, J.W.; Bender, R.H.W.; Zhang, P.; Wrobel, J.E.; et al. Preparation of oxospiro[cycloalkane-1,3'-indoline]derivatives and analogs as progesterone receptor antagonists. WO 0066167 PCT Intern. Pat. Appl., Nov 9, 2000. Chem. Abstr. 2000, $133,350135$.

32. Fensome, A.; Zhang, P.; Koko, M.C.; Zhi, L.; Jones, T.K.; Marschke, K.B.; Tegley, C.M. Preparation of thioxospiro[cycloalkane-1,3'-indole]derivatives and analogs as progesterone receptor agonists. WO 0066555 PCT Intern. Pat. Appl., Nov 9, 2000. Chem. Abstr. 2000, 133, 350136.

33. Fensome, A.; Miller, L.L.; Ullrich, J.W.; Bender, R.H.W.; Zhang, P.; Wrobel, J.E.; Zhi, L.; Jones, T.K.; Marschke, K.B.; Tegley, C.M. Preparation of indolinones as progesterone antagonists. WO 0066556 PCT Intern. Pat. Appl., Nov 9, 2000. Chem. Abstr. 2000, 133, 350137.

34. 3-Methylation of 3-methyl-6-methoxyoxindole (2.0 eq BuLi, 2.0 eq TMEDA, 1.14 eq MeI, THF, $-78^{\circ} \mathrm{C}$, flash chromatography, 82\%) is described in: Jayyosi, Z.; McGeehan, G.M.; Kelley, M.F.; Labaudiniere, R.F.; Zhang, L.; Groneberg, R.D.; McGarry, D.G.; Caulfield, T.J.; Minnich, A.; Bobko, M. Preparation of diaryl carboxylic acids and derivatives as peroxisome proliferator-activated receptor ligands. WO 0064888 PCT Intern. Pat. Appl., Nov 2, 2000. Chem. Abstr. 2000, 133, 335167.

35. Reaction (2.0 eq BuLi, 2.0 eq TMEDA, THF, $25{ }^{\circ} \mathrm{C}, 60 \%$ ) of 5-bromo-3-methyloxindole with $\mathrm{BrCH}_{2} \mathrm{CO}_{2} \mathrm{Et}$ (1.0 eq) is described in: Jiang, T.; Kuhen, K.L.; Wolff, K.; Yin, H.; Bieza, K.; Caldwell, J.; Bursulaya, B.; Wu, T.Y.-H.; He, Y. Design, synthesis and biological evaluations of novel oxindoles as HIV-1 non-nucleoside reverse transcriptase inhibitors. Bioorg. Med. Chem. Lett. 2006, 16, 2105-2108. [CrossRef] [PubMed]

36. Volk, B.; Barkóczy, J.; Hegedús, E.; Udvari, S.; Gacsályi, I.; Mezei, T.; Pallagi, K.; Kompagne, H.; Lévay, G.; Egyed, A.; et al. (Phenylpiperazinyl-butyl)oxindoles as selective 5-HT 7 receptor antagonists. J. Med. Chem. 2008, 51, 2522-2532. [CrossRef] [PubMed]

37. Volk, B.; Gacsályi, I.; Pallagi, K.; Poszávácz, L.; Gyönös, I.; Szabó, É.; Bakó, T.; Spedding, M.; Simig, G.; Szénási, G. Optimization of (arylpiperazinylbutyl)oxindoles exhibiting selective $5-\mathrm{HT}_{7}$ receptor antagonist activity. J. Med. Chem. 2011, 54, 6657-6669. [CrossRef] [PubMed]

38. For methylation using trimethyloxonium tetrafluoroborate, see: Zhou, H.-J.; Wang, J.; Yao, B.; Wong, S.; Djakovic, S.; Kumar, B.; Rice, J.; Valle, E.; Soriano, F.; Menon, M.-K.; et al. Discovery of a first-in-class, potent, selective, and orally bioavailable inhibitor of the p97 AAA ATPase (CB-5083). J. Med. Chem. 2015, 58, 9480-9497. [CrossRef] [PubMed]

39. For ethylation of unsubstituted oxindole using triethyloxonium tetrafluoroborate, see: Harley-Mason, J.; Leeney, T.J. 2-Ethoxyindoles and -indolenines. A case of indole-indolenine tautomerism. Proc. Chem. Soc. Lond. 1964, 368-369.

40. Tóth, F.; Fráter, G.; Ondi, L. Compounds and the use thereof in metathesis reactions. WO 2015155593 PCT Intern. Pat. Appl., Oct 15, 2015. Chem. Abstr. 2015, 163, 585851.

41. Borovik, V.P.; Gatilov, Y.V.; Shkurko, O.P. Reaction of 3-(R-methylidene)-2-ethoxylindolenines with $N, N^{\prime}$-binucleophiles. Russ. J. Org. Chem. 2016, 52, 228-234. [CrossRef]

42. For ethylation of 5-chlorooxindole using triethyloxonium tetrafluoroborate, see: Esses-Reiter, K.; Reiter, J. Attempted synthesis of a tenidap isomer and formation of an unexpected stable water adduct. J. Het. Chem. 2000, 37, 927-933. [CrossRef]

43. For ethylation of 3-methyloxindole using triethyloxonium tetrafluoroborate, see: Nakagawa, M.; Hino, T. 2-Ethoxy and 2-ethylthioindoles. Autoxidation and nucleophilic substitutions. Tetrahedron 1970, 26, 4491-4503. [CrossRef]

44. Hino, T.; Nakagawa, M.; Akaboshi, S. 2-Ethoxyindoles and 2-ethylthioindoles: their autoxidation and reactions with piperidine. Chem. Commun. 1967, 656-658. [CrossRef]

45. For $\mathrm{O}$-alkylation with ethyl diazoacetate in the presence of $\mathrm{Rh}_{2}\left(\mathrm{OCOCF}_{3}\right)_{4}$, see: Busch-Petersen, J.; Corey, E.J. Rhodium(II) catalytic approach to the synthesis of ethers of a minor component in a tautomeric set. Org. Lett. 2000, 2, 1641-1643. [CrossRef] [PubMed]

46. For the introduction of a monofluoromethyl moiety to the oxygen atom using $\mathrm{N}, \mathrm{N}$-(dimethylamino)-S-phenyl-S-monofluoromethyloxosulfonium hexafluorophosphate in the presence of tert-butylimino-tris(dimethylamino) phosphorane, see: Nomura, Y.; Tokunaga, E.; Shibata, N. Inherent oxygen preference in enolate monofluoromethylation and a synthetic entry to monofluoromethyl ethers. Angew. Chem. Int. Ed. 2011, 50, 1885-1889. [CrossRef] [PubMed] 
47. Bai, M.; You, Y.; Chen, Y.-Z.; Xiang, G.-Y.; Xu, X.-Y.; Zhang, X.-M.; Yuan, W.-C. An unprecedented protocol for the synthesis of 3-hydroxy-3-phenacyloxindole derivatives with indolin-2-ones and $\alpha$-substituted ketones. Org. Biomol. Chem. 2016, 14, 1395-1401. [CrossRef] [PubMed]

48. Green, J.R. Science of Synthesis; Majewski, M., Snieckus, V., Eds.; Georg Thieme Verlag: Stuttgart-New York, Germany, 2006; Volume 8a, pp. 427-486.

49. Clugston, M.; Fleming, R. Advanced Chemistry; Oxford University Press: Oxford, United Kingdom, 2000.

50. Volk, B.; Simig, G. New one-pot synthesis of 3-alkyl- and 3-( $\omega$-hydroxyalkyl)oxindoles from isatins. Eur. J. Org. Chem. 2003, 3991-3996. [CrossRef]

51. Drug candidates with a 5-substituted oxindole skeleton are as follows: Tenidap, famitinib, and satavaptan (Phase III); cipargamin, amcasertib, adibendan, NS-1209 and indolidan (Phase II).

52. Takayma, K.; Isobe, M.; Harano, K.; Taguchi, T. A general synthetic route of 3,3-disubstituted $3 H$-indoles and rearrangement of their acyl chloride adducts. Tetrahedron Lett. 1973, 14, 365-368. [CrossRef]

53. Fan, J.-H.; Zhou, M.-B.; Liu, Y.; Wei, W.-T.; Ouyang, X.-H.; Song, R.-J.; Li, J.-H. Iron-catalyzed oxidative arylmethylation of activated alkenes using a peroxide as the methyl source. Synlett 2014, 25, 657-660. [CrossRef]

54. Hseih, J.-C.; Cheng, A.-Y.; Fu, J.-H.; Kang, T.-W. Copper-catalyzed domino coupling reaction: an efficient method to synthesize oxindoles. Org. Biomol. Chem. 2012, 10, 6404-6409. [CrossRef] [PubMed]

55. Taylor, A.M.; Altman, R.A.; Buchwald, S.L. Palladium-catalyzed enantioselective $\alpha$-arylation and $\alpha$-vinylation of oxindoles facilitated by an axially chiral P-stereogenic ligand. J. Am. Chem. Soc. 2009, 131, 9900-9901. [CrossRef] [PubMed]

56. Braudeau, E.; David, S.; Fischer, J.-C. 2-Hydroxyindoxyls. General and novel preparation, properties, and their role in the perphthalic acid oxidation of indoles. Tetrahedron 1974, 30, 1445-1455. [CrossRef]

57. Nakazaki, A.; Mori, A.; Kobayashi, S.; Nishikawa, T. Diastereoselective synthesis of 3,3-disubstituted oxindoles from atropisomeric N-aryl oxindole derivatives. Tetrahedron Lett. 2012, 53, 7131-7134. [CrossRef]

Sample Availability: Samples of the compounds $9 \mathbf{c}-\mathbf{u}$ are available from the authors.

(C) 2016 by the authors; licensee MDPI, Basel, Switzerland. This article is an open access article distributed under the terms and conditions of the Creative Commons Attribution (CC-BY) license (http://creativecommons.org/licenses/by/4.0/). 